\title{
2. Shaping Identity through Glass in Renaissance Venice
}

\author{
Rachele Scuro
}

\begin{abstract}
:
This essay investigates the role of the glass business in shaping the identity of glassmakers in Renaissance Venice. First, it re-examines the debated issue of secretiveness, highlighting the role played by immigration and emigration, and stressing how mobility affected the intersection between secrets and the creation of a distinctive identity. It then focuses on trade, examining the role played by the Venetian high political bodies in protecting a manufacturing that became a matter of state. It argues that thanks to government protection the participation of glass entrepreneurs in commerce did not need any formal branding, yet only to be recognized as "Venetian." Lastly, the case study of the Bortolussi family shows the strategies of those glassmakers who tried to ascend to a superior social status, that of Venetian "cittadini originari."
\end{abstract}

Keywords: Renaissance Venetian glass; early modern Venetian economy; Venetian citizenship; Venetian glass entrepreneurship; early modern Venetian glass; early modern Venetian society

A long-established tradition associates Venetian glass with the idea of secretiveness, a self-constructed myth that was later bequeathed from the Serenissima to modern historiography. In fact, during the medieval and early modern period, the aim to prevent the spread of the secreti found concrete basis in legislation that prohibited glassmakers to emigrate. Scholars have consequently read this recurring series of orders and reprimands as proof of the active role played by Venice in protecting an expertise that should have remained unshared and guarded as "property" that was not only typical of a master or a professional

Burghartz, S., L. Burkart, C. Göttler, U. Rublack, Materialized Identities in Early Modern Culture, 1450-1750: Objects, Affects, Effects. Amsterdam: Amsterdam University Press, 2021 DOI 10.5117/9789463728959_CHO2 
group, but of the city itself. ${ }^{1}$ This set of protectionist strategies was shared among the republic, the glassmakers' guild, and its entrepreneurs. ${ }^{2}$ Secrets became an instrument to mark a distinctive knowledge that had to be protected from anyone outside the city and its workers, who were seen as their sole, rightful owners. ${ }^{3}$

Yet, following Koen Vermeir's analysis, the concepts of secrecy and openness should no longer be read as mere opposites. ${ }^{4}$ Furthermore, the very notions of secrets and secrecy have to be distinguished, as there can be secrets without secrecy (e.g. simple recipes, skills, or techniques), as well as secrecy without actual secrets. Secrecy and openness are thus norms or values that regulate behaviours, and characteristics of practices that can be modulated by a rhetorical play decided by the actors involved. It follows that in order to differentiate between types of secrecy based on the actors, the discussion needs to be historicized. Moreover, regarding the ideas of both "open" and "secret," it is important to specify the "by whom" and "for whom." For instance, can a secret kept by a group of hundreds of people still be considered as such? ${ }^{5}$ This is also the case for the community of glass workers in Murano and Venice, for whom an interpretation of openness and secrecy as gradational categories can be applied. The two are thus seen as positive categories about which the central question remains, who actually had access to that knowledge? ${ }^{6}$ Is it possible to rethink secrecy in the Muranese environment as an "open secret"? ${ }^{7}$ And if so, what were its effects on the creation of a group identity? ${ }^{8}$

1 Paolo Preto, I segreti di Venezia. Spionaggio e controspionaggio ai tempi della Serenissima (Milan: il Saggiatore, 2010), 403-422.

2 For an excursus on the history of Venetian glass, see Rosa Barovier Mentasti, "La vetraria veneziana," in Storia di Venezia. Temi. L'Arte, ed. Rodolfo Pallucchini, vol. 2 (Rome: Treccani, 1995), 845-905. The most famous scholar on Murano glass was Luigi Zecchin, whose works are now collected into three volumes, see Luigi Zecchin, Vetro e vetrai. Studi sulla storia del vetro, 3 vols. (Venice: Arsenale Editrice, 1987-1990). They followed the study of Astone Gasparetto, Il vetro di Murano dalle origini ad oggi (Vicenza: Neri Pozza, 1958). More recently the technological and labour market aspects of early modern Venetian glass have been analysed by Patrick McCray, Glassmaking in Renaissance Venice: The Fragile Craft (Aldershot: Ashgate, 1999) and Francesca Trivellato, Fondamenta dei vetrai. Lavoro, tecnologia e mercato a Venezia tra Sei e Settecento (Rome: Donzelli, 200o).

3 On the topic of secretiveness in early modern arts and crafts, see Sven Dupré and Christine Göttler, eds., Knowledge and Discernment in the Early Modern Arts (London: Routledge, 2017) and Timothy McCall, Sean Roberts, and Giancarlo Fiorenza, eds., Visual Cultures of Secrecy in Early Modern Europe (Kirksville, MO: Truman State University Press, 2013).

4 Koen Vermeir, "Openness versus Secrecy? Historical and Historiographical Remarks," The British Journal for the History of Science 45, no. 2 (2012): 166-167.

5 Ibid., 169 .

6 Ibid., 171-172.

7 An "open secret" can be open and secret concurrently, for instance, it can be intentionally concealed or denied to a larger audience, while actively discussed within a select group; Vermeir, "Openness," $175^{-176 . ~}$

8 On the effects of secrecy in the development of identitarian categories, see Georg Simmel, "The Sociology of Secrecy and of Secret Societies," American Journal of Sociology 11, no. 4 (1906): 441-498. 
Starting from these questions, this analysis aims at investigating the role played by Muranese glass industry members in shaping the inner identity of the group, as well as their identitarian relationship with Venice. I will open my analysis by re-examining the debated issue of secretiveness and openness with regard to the group's internal practices, to highlight the effects played by both immigration and emigration, and the transfer of knowledge resulting from the labour organization and geographic peculiarities of the island. I will also stress how the mobility of craftspeople, who moved between the furnaces of the island, of Italy, and then of Europe, affected the intersection between secrets and the creation of a shared identity that was professional, cultural, and social.

I will then transfer the connection existing between the material and its crafters to a larger perspective to include the institutional aspects along with other socio-economic factors that linked this bond to Venice as a city and a state. I will analyse the synergy existing between glassmakers and the Venetian high political bodies to protect an industry which, due to the international success it had reached through its luxury output, had become a matter of state. I will argue that, as a result of governmental shielding, glass entrepreneurs did not need any formal brand or label other than being recognized as Venetian. Thus, the identitarian sense maintained by the oligopolistic families leading the branches merged with the name of Venice itself, as had happened to the commodities produced in their furnaces. At the same time, the state was actively promoting a policy aimed at benefiting from international recognition and the positive effects on the local economy deriving from the high-end production of glass, as well as, if not mainly, from its mass production.

In the final section I will use the case study of the Bortolussi family to examine the strategies of social ascent designed by those glassmakers who, from the second half of the sixteenth century, aspired to transcend their original status and reach the highest rank for non-nobles within Venetian society, that of the cittadini originari of Venice. Literature has usually argued that glassmakers only resorted to this when familial strategies pointed to alternative careers for some individuals in the kinsgroup. On the contrary, I will consider how the process intertwined with the evolution of a self-identitarian definition of the leading glass families, which in turn progressed thanks to their economic success and exogamic marriage strategies. I will also analyse how this aspiration to receive official recognition as belonging to the higher social ranks of the capital was helped by the monopolistic position they held in an industry that, since the last part of the previous century, had become economically strategic as well as linked to both a material and a mastery essential to the representation of Venice in the world. 


\section{Secretiveness and Identity: The Circulation of People and Knowledge}

The idea of strict secretiveness around the matter of glass expertise and workmanship, as traditionally presented in literature, is largely contradicted by Venetian archival sources. In fact, between the fifteenth and sixteenth centuries, the composition of the population of the Muranese glassmakers showed a strong rate of mobility, as proved by sources like notarial contracts and inventories, or the jurisdictional documentation in the registers of the Podestà di Murano, the Venetian officer in charge of the island as the local representative of the central power. Moreover, the trend applies to both workers coming to the island and to local glassmakers who decided to leave the Lagoon to move abroad or to the newly acquired subject cities of the mainland state.

During the first half of the fifteenth century, a robust immigration rate can be observed from the sources. This was a consequence of the policies adopted by Venice to encourage artisan immigration after the Black Death and the War of Chioggia (1378-1381). The trend continued up to the beginning of the sixteenth century, thanks to the integration of the mainland state into the capital's economy during the Quattrocento. ${ }^{9}$ Notably, these latecomers constituted some of the most important glassmaker families of the early modern period, such as the Bortolussis, who will be analysed later in this chapter. These initial observations encourage widening the traditional perspective on the Venetian glass industry, including recognition of its place within the circulation of material skills and knowledge in Renaissance Italy and Europe. ${ }^{10}$

The flow of manpower and knowledge is significantly proved by the provenance of those immigrants, which can be pinpointed to three main areas. Firstly, the towns of the Po valley, in particular those of the newly conquered Veneto; secondly, the Dalmatian area, the traditional birthplace of many workers in the Venetian manufacturing industry; ${ }^{11}$ and thirdly, Tuscany, a region in which the glass industry had already developed high degrees of specialization and diffusion of its products. ${ }^{12}$ The stability of the new arrivals was also remarkable: they were usually able to settle down in Murano and find a prominent place within the glass industry in a short period of time, thus becoming fully integrated within the local community by the first or second generation.

Furthermore, despite the first half of the fifteenth century having usually been considered a moment of crisis for the Muranese glass industry, a certain level of

9 On trends and examples in the case of glassmakers, refer to Zecchin, Vetro, 3:191-198.

10 Corinne Maitte, "Larte del vetro; innovazione e trasmissione delle tecniche," in Il rinascimento italiano e l'Europa, vol. 3: Produzione e tecniche, ed. Philippe Braunstein and Luca Molà (Vicenza: Angelo Colla, 2007), 236.

11 From that region came, for instance, the families Caner and Ballarin; see Zecchin, Vetro, 1:202-206.

12 Guido Taddei, L'arte del vetro in Firenze e nel suo dominio (Florence: Le Monnier, 1954). 
vitality is instead proved by the contrary emigration rate. This trend involved not only the foreign segment of the manpower, but also local families of established tradition. In most cases, the latter chose nearby destinations, and decided to move to cities of the mainland state, counting on a set of fiscal and trade privileges accorded by the capital to the new subject districts. As a consequence, in contrast to the traditional idea of Murano being the only place where glass could be manufactured within the Venetian state, in a brief span of time Padua, Vicenza, and above all Treviso, ${ }^{13}$ saw the opening of new furnaces owned and managed by Muranese glassmakers. ${ }^{14}$

Although the prohibition to export manpower outside of Murano had been a cornerstone in the regulation of the guild since its first statutes, ${ }^{15}$ it had also been traditionally accepted, de facto if not by law, that workers would resort to seasonal expatriations. To justify their temporary transfer, glassmakers had for centuries claimed that emigration was forced on them due to the constraints created by Venetian laws, in particular the imposition of an excessively long period of vacanza for the furnaces in Murano (i.e. the period when fires had to stay out, which initially was for five months). In these circumstances, emigration was claimed to be the only viable solution to extend the glassmakers' working season, in order to sustain their families and business. ${ }^{16}$ However, this reason does not sufficiently explain their emigration trends by the end of the Middle Ages. Firstly, because during the fifteenth century the state actively tried to overcome the previous medieval directive by extending the annual working period. ${ }^{17}$ Secondly, because for many, the months spent working outside Murano were not at all coincidental with the shutdown required by the regulation.

Thus, although legislation had on the one hand been insistently condemning expatriation since the Middle Ages, on the other hand Renaissance glassmakers as a community did not usually see a temporary transfer as a deplorable choice, and the official protectionist intents found less support once faced with personal, familial, and group issues. In general, a certain degree of mobility was never seen

13 Zecchin, Vetro, 2:318-326. On the individualistic attitude of Muranese migrants: Corinne Maitte, "Les migrations de travail comme ressources: verriers altarais et vénitiens, XVIe-XVIIIe siècle," Mélanges de l'École française de Rome 123, no. 1 (2011): 3-9.

14 Bergamo, at the western corner of the Terraferma, was initially the single authorized exception. However, by the middle of the fifteenth century, furnaces were permitted in the subject cities, but were only allowed to produce low-quality glass. Trivellato, Fondamenta, 223.

15 Giovanni Monticolo, ed., I capitolari delle arti veneziane sottoposte alla Giustizia e poi alla Giustizia Vecchia. Dalle origini al MCCCXXX, vol. 2 (Rome: Istituto Storico per le Fonti della Storia d'Italia, 1905), 66.

16 Once on trial, these were the typical justifications glassmakers gave.

17 At the beginning of the sixteenth century, the vacanza was finally fixed between the end of July and the beginning of October. On the regulation of the annual putting out of the furnaces through the fifteenth and sixteenth centuries, see Paolo Zecchin, "La cavata dei vetrai muranesi," Rivista della Stazione Sperimentale del Vetro 5 (1995): 207-218. 
as reprehensible until a later period, ${ }^{18}$ and never implied difficulties for reinsertion into the social life and job market of the island. Therefore, the relocation of some Muranese glassmakers to cities of the Terraferma at the beginning of the Quattrocento anticipated what was going to develop further over the following centuries: that the chance to move to other Italian and European areas, for short or long periods, was perceived as a natural one if it could sufficiently justify the losses in Venice by providing more significant earnings. ${ }^{19}$

From this perspective, the concepts of "secret" and "secretiveness" in the Venetian glass industry need to be considered through the interrelation between familial and professional bonds, especially because Muranese society was still quite homogeneous up to and during the fifteenth century. ${ }^{20}$ Additionally, the positioning of all the furnaces in a limited space, in the form of one parish and the two banks along the canal rio dei verieri, reinforced the exchange of people and knowledge (Fig. 2.1). In this context, technological and stylistic innovations could not remain secret; on the contrary, they were to be shared and become a "collective identifier."

This hypothesis is sustained by the manufacturing organization of the furnaces: different to today, the creation of a single object was divided into many phases, each one entrusted to a different master or worker with different specializations and skills. ${ }^{21}$ Workers were also accustomed to working side by side, thus becoming familiar with all the stages of production as viewers if not as makers, regardless of their age, level of experience, or status within the workshop. Knowledge was, therefore, seamlessly passed down from one person to the next through physical presence in the workshop and observation.

Moreover, within the local industry the staff - both masters and unspecialized labourers - were usually characterized by a high rate of mobility, as work contracts

18 The offender was often reported by close relatives, likely due to previous arrangements within the family to reduce the de facto outlay of the fixed pecuniary fine, which was to be partially given to the denouncer. Examples in ASVe, PodMur, b. 19, fasc. 1, c. 115v (17.01.1446) and b. 116-117, c. 240r (25.05.1598). 19 By the middle of the sixteenth century, this tendency had become a chronic problem that the state tried in vain to resolve; see BMC, IV L 13, ch. 131, cc. 49r-52r (28.02.1543mv); ch. 135, c. 53r-v (27.10.1547); ch. 137, cc. 55r-56r (18.09.1549); ch. 147, c. $63 \mathrm{v}$ (18.11.1597). For instance, in 1569, Battista Guado and Gianandrea Barovier were denounced for having moved to Antwerp (ASVe, PodMur, b. 71, c. 1123r [14.02.1569]).

20 The masters who owned the workshops had far more resources than most of their employees, yet still in the Quattrocento it was common for them to work at their furnace in person, thus developing a sense of strong familiarity with their personnel. Furthermore, in a small island like Murano, closeness helped to create a sense of group identity: the place of work and residence were merged in a sense of community. This explains why professional endogamy was quite common there, in contrast to other Venetian guilds (see Dennis Romano, Patricians and Popolani: The Social Foundations of the Venetia Renaissance State [Baltimore, MD and London: Johns Hopkins University Press, 1987], 77-79).

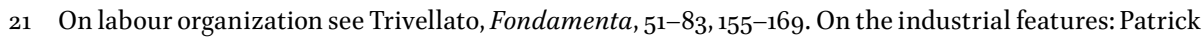
McCray, "Creating Networks of Skill: Technology Transfer and the Glass Industry of Venice," Journal of European Economic History 28, no. 2 (1999): 301-303. 


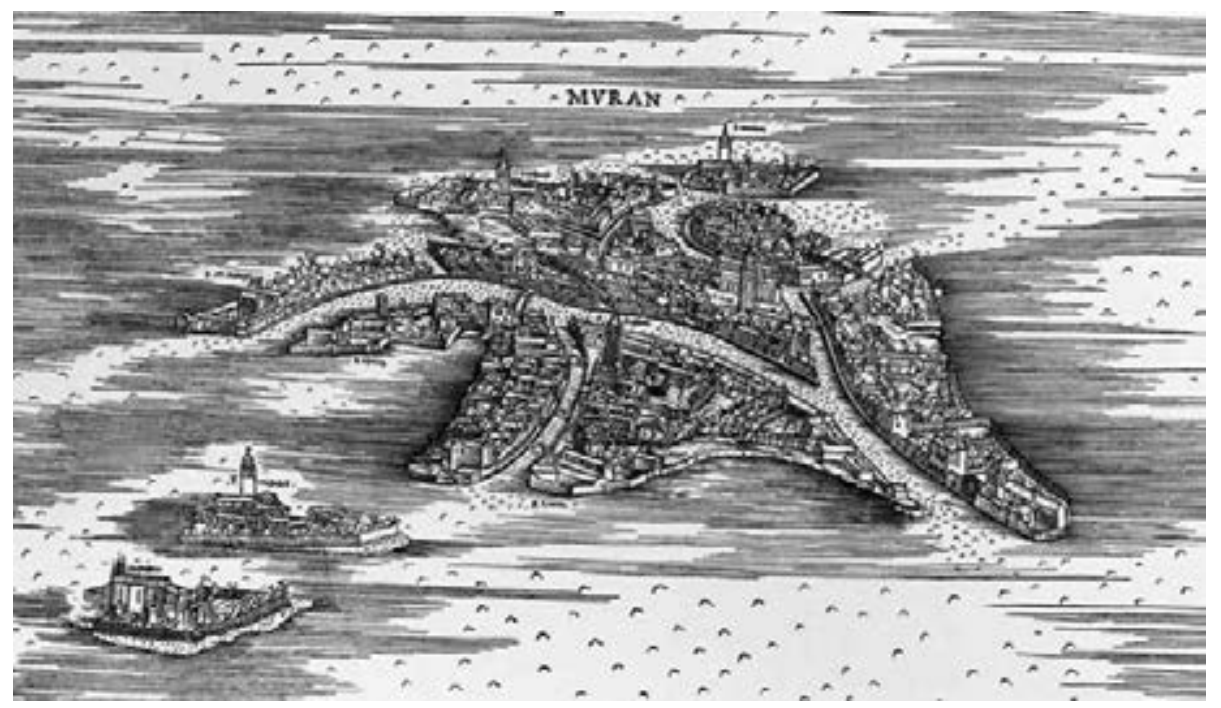

Figure 2.1: Jacopo de Barbari, View of Venice, 1500. Woodcut, detail: The island of Murano. In the lower part, crossed by three bridges, is the canal called the "rio dei verieri" with its workshops overlooking the two quays. Venice, Museo Correr, inv. Cl. XLIV n. 0057. Image 2020 @ Photo Archive - Fondazione Musei Civici di Venezia.

were normally agreed for one year only, corresponding to the working year fixed by the Venetian regulation. Both masters and workers usually changed their place of work annually, to pursue better working and salary conditions. This resulted in a steady flow of skills and craftsmanship, in addition to other parallel ways of sharing knowledge, such as family and neighbourhood relationships. Within one or two years, a large part of the manpower would have changed their workplace and thus would have transferred from one furnace to another any sort of innovation or "secret" previously acquired.

From a fashion point of view, not even that short span of time was necessary to disseminate new trends, as the proximity of shops and furnaces would have spread any novelty within days or months once objects had been put on display and seen by other experienced masters. Therefore, if the annual rotation of employees could perhaps have avoided, for example, the diffusion of the secret for a specific shade of enamel - at least for some years - it was nonetheless unlikely that the manual process to obtain rosette beads, filigree glass, or any other new method or trend could remain concealed within a single furnace for very long, after being crafted in front of other colleagues. ${ }^{22}$ It was that embodied craftsmanship that created, on the one

22 Practice would have done the rest, possibly bringing about even more ingenious innovations. Recipe books (focused on chemical aspects) could not protect more than a share of the "secret," while the industry's success largely remained in artisans' embodied knowledge. Additionally, "making" expertise 
hand, a common, shared knowledge and a set of valuable skills transferable only by practice with masters, ${ }^{23}$ and on the other, a sense of community and identity based on sharing a mastery unknown to other glass centres, with secrecy as a dynamic process creating special bonds and a sense of community. ${ }^{24}$

The rapid spread of knowledge within the boundaries of Murano is shown even in the paradigmatic case of the process of refinement that led to the creation of crystal glass and ushered in Venetian glassware's season of undisputed fame. Around the 145 os a new type of vetro cristallino made its appearance, tied to the business of the Barovier family. The Baroviers themselves, however, were the first to share their expertise and to work in partnership with other glassmakers. Apparently, not even this "invention" was perceived as a long-lasting, distinctive secret for a single family or workshop, regardless of the fact that they had sensed its potential on the market.

In 1460 a contract stipulated between Taddeo Barovier, head of the fraterna, ${ }^{25}$ and master Bartolomeo Visentin is one such example: the two joined their business for ten years with the aim of opening a new furnace to produce crystalware. ${ }^{26}$ Two elements are particularly relevant. First, Visentin was a first-generation newcomer to Murano, ${ }^{27}$ but had nevertheless already learnt the techniques to produce cristallo and was so well instructed as to be put at the head of the workshop as the working

could not be transferred through text without the imitation process possible only in the workshop. Glassmakers had to design processes to gain the expected result, but these were largely tacit skills that require training and time, and a stimulating co-working workspace. On reconstructing craftsmanship and technical knowledge from written texts in the case of Renaissance recipe books, see Pamela $\mathrm{H}$. Smith, "Historians in the Laboratory: Reconstruction of Renaissance Art and Technology in the Making and Knowing Project," Art History 39, no. 2 (2016): 210-233. On embodied knowledge, see the interesting considerations in the video by the glassmaker Ian Hankey: Hankey, video contribution to Ways of Making and Knowing: The Material Culture of Empirical Knowledge, ed. P. H. Smith, A. R. W. Meyers, and H. J. Cook (Chicago, IL: University of Chicago Press, 2014), accessed on 19 August 2019, https://www.youtube.com/ watch?v=sSBY6Lc2-hU.

23 This was clear to the Tuscan priest Antonio Neri, the first divulgator on Venetian glass, who in 1612 published his glassmaking manual L'Arte vetraria. At the end of the recipe for flux to make crystal glass, he ruminated that experience makes a person discover and learn more than any long study, aware of the impossibility to transfer in a sentence that tacit expertise; Antonio Neri, L'Arte vetraria. 1612, ed. Rosa Barovier Mentasti (Milan: Il Polifilo, 1980), ch. 6, 8. See also McCray, “Creating," 316-323.

24 Koen Vermeir and Dániel Margócsy, "States of Secrecy: An Introduction," The British Journal for the History of Sciences 45, no. 2 (2012): 161, 164.

25 On the typical fraterna system: Frederic C. Lane, "Family Partnership and Joint Venture in the Venetian Republic," The Journal of Economic History 4, no. 2 (1944): 178-196.

26 ASVe, PodMur, b. 26, fasc. 2, sd (01.10.1460). Taddeo probably intended to add crystal glass to the products he already traded overseas.

27 He must have been very young on his arrival, as in 1420, he was denounced for having worked outside Murano. At that time, he was still called "from Vicenza," the provenance from which originated the family surname; see Zecchin, Vetro, 3:39. 
partner and supervisor to the manufacturing process. Probably one of the Baroviers had taught him the "secret" technology. Nonetheless, it is remarkable that Taddeo chose him among the others without fear of sharing the innovation with someone whose kin had not been living in Murano for generations. Moreover, the basis of the method was probably already diffused among the majority of workers on the island, while only the subtlest phases of the refinement process were yet to be widespread. ${ }^{28}$

Secondly, in case of a premature break of the agreement, the Visentins swore to conceal the expertise acquired if they were to find a new employer, although that would not have applied were the break due to the decision to open their own furnace. After all, ten years was generally considered the customary time frame to protect the outcome of an innovation, a period of time long enough to guarantee a patent and to compensate future losses coming from the diffusion of the new methods. ${ }^{29}$ In sum, not even crystal glass, the material that granted Venetian glassware permanent success within the world's imagery of luxury and elegance, was preserved as a secret according to our modern understanding, but as a community "open secret."

The aim then was not to prevent the sharing of secrets in the Lagoon but their leakage outside its borders. In fact, once makers acquired the technical skills and the manual dexterity, Venice provided an easy supply of the necessary raw materials, often imported from abroad; namely, ashes from Syria or pebbles from the Ticino river. ${ }^{30}$ These (or similar) materials could, however, have been shipped to many other parts of the peninsula or the continent, where a well-equipped master would have been able to produce the same items if possessing the right craftsmanship.

As a consequence, the Serenissima's attention towards the glass industry and its "secrets" strengthened when the fame of crystal glass started to be highly valued in an international context. The capacity to maintain a monopoly on the production of this innovation went from being a family and community affair to a state concern, pursued by the highest bodies of the republic. This also enhanced the perception of these secrets as typically Venetian. With the recent involvement of the government,

28 A $145^{8}$ ducal letter shows that the Mozetos and Angelis were producing crystal glass too; ASVe, PodMur, b. 23, $s d\left(21.02 .145^{8}\right)$.

29 The republic usually granted patent privileges for the same length of time; see Carlo Poni and Roberto Breveglieri, "Three Centuries of Venetian Patents 1474-1796," Acta historiae rerum naturalium nec non technicarum 17 (1982): 381-393 and Luca Molà, "Inventors, Patents and the Market for Innovations in Renaissance Italy," in Italian Technology from the Renaissance to the Twentieth Century, ed. Anna Guagnini and Luca Molà, 7-34, History of Technology 32 (London: Bloomsbury, 2014) and Luca Molà, "Stato e impresa privilegi per l'introduzione di nuove arti e brevetti," in Braunstein and Molà, Il rinascimento, 3:533-572. 30 Eliyahu Ashtor and Guidobaldo Cevidalli, "Levantine Alkali Ashes and European Industries," Journal of European Economic History 12, no. 3 (1983): 475-522; David Jacoby, "Raw Materials for the Glass Industries of Venice and the Terraferma, about 1370 - about 1470," Journal of Glass Studies 35 (1995): 65-90. 
once the material became strategically associated with other luxury crafts of the city (including silk), ${ }^{31}$ secretiveness surrounding crystal and glass became not only a concern for the glassmakers as a collective body, but for the republic as a whole, protecting not only an industry but the state's reputation and its public representation. This is because Venice was employing the fascination of secrecy to strengthen its trading position, based on the notion that those aware of the secret, but who did not have access to it, would desire crystal glass more fervently. ${ }^{2}$

Thus, in contrast to earlier times, ${ }^{33}$ the migration of masters was no longer condoned because the professional, internal "secrets" they took with them had in the meantime become secrets of state, or a state "brand." Besides, the migration of skills was worsening a situation in which even non-Venetian glassmakers abroad were developing and producing items by imitation, the so-called façon de Venise glassware. ${ }^{34}$ This included, for instance, the glassmakers of Altare, who had shared knowledge of the Muranese technology since the later Middle Ages. ${ }^{35}$

As a result, the government took the role of guarantor for the Muranese branch to protect its fragile internal and external equilibrium..$^{6}$ From the second half of the sixteenth century it strengthened its opposition to any form of migration and proliferation of technical knowledge outside the Lagoon, with the aim of preserving the iconic image of its glass industry, dynamized too by a foreign narrative of distinction. The state therefore recognized the distinction of the industry from the perspective of a common identification. This process was not dissimilar to the myth of Venice itself and the self-construction of an ideal to be displayed in front of both foreigners and Venetians alike. ${ }^{37}$ In this sense, the idea of secrets per se was not oriented to a single individual or group but to Muranese-Venetian glassmaking

\footnotetext{
31 See Luca Molà, The Silk Industry of Renaissance Venice (Baltimore, MD and London: Johns Hopkins University Press, 200o).

32 Vermeir and Margócsy, "Introduction," 161.

33 This share of knowledge during the Middle Ages is indirectly proved by linguistic analysis of recipe books, which owed much to the Muranese vernacular; Cesare Moretti, Carlo Stefano Salerno, and Sabina Tommasi Ferroni, eds., Ricette vetrarie muranesi. Gaspare Brunoro e il manoscritto di Danzica (Florence: Nardini Editore, 2001), 23-27.

34 The rise of furnaces working products in the Venetian style in various European regions will not be touched on in this chapter. For a general overview, see the following volumes: Johan Veeckman, Sarah Jennings, et al., eds., Majolica and Glass: From Italy to Antwerp and Beyond. The Transfer of Technology in the 16th-17th Century (Antwerp: Stad Antwerpen, 2002) and Jutta-Annette Page, ed., Beyond Venice: Glass in Venetian Style, 1500-1750 (Manchester, VT: The Corning Museum of Glass, 2004).

35 On the relationship between the Altarese glass masters and Europe, especially in the French context, see Corinne Maitte, Les Chemins de verre. Les migrations des verriers d'Altare et de Venise (XVIe-XIXe siècle) (Rennes: Presses Universitaires de Rennes, 2009).

36 Trivellato, Fondamenta, $5^{1-84}$.

37 On the myth of Venice and its self-representation as a state, a civitas, and a communitas, see Robert Finlay, “The Immortal Republic: The Myth of Venice during the Italian Wars (1494-1530)," The
} 
as an emanation of the republic. Only at a second stage would it imply the modern concept of competition among single entrepreneurs.

\section{Branding without a Brand: Trading Strategies in Venetian Glassmaking}

As highlighted by Corinne Maitte, the international success of Murano glassware in the Renaissance had a strong impact on the identification of the material with Venice and Murano in following centuries, distorting the fact that the island was not the only place where it was worked. ${ }^{38}$ Furthermore, the position given to luxury crystalware in the majority of studies has skewed analysis on the nature of the Venetian industry, as research has generally focused solely on its high-end output, neglecting the fact that glass was mainly a mass-produced artefact.

This situation is only apparently contradicted by the fact that Venetian glass was never branded until recent times and that even individual labels were not used, with the exception of shop signs that in many cases became the surname of the families who owned them. ${ }^{39}$ While a buyer entering a shop in Murano might have recognized that name (and possibly its reputation), a foreign customer would not have had the same awareness. Nevertheless, no different to today, it is undeniable that the association of Venice with glass was almost unanimously perceived as a sort of brand and a promise of quality.

The innovations created in Renaissance Venice projected that reputation further, stressing the material's pliability and shininess that allowed objects of increased artistic value to be produced. These innovations were also the result of shifting early modern attitudes towards material culture that merged an interest in materials' alchemical aspects with new concepts of value: ${ }^{40}$ the latter not residing in intrinsic corporeal attributes so much as in the mastery of artifices..$^{41}$ In other words, virtuoso

Sixteenth-Century Journal 3o, no. 4 (1999): 931-944 and James S. Grubb, "When Myths Lose Power: Four Decades of Venetian Historiography," The Journal of Modern History 58, no. 1 (1986): 43-94.

38 Corinne Maitte, “Façon de Venise: Determining the Value of Glass in Early Modern Europe," in Concepts of Value in European Material Culture, 1500-19oo, ed. Bert de Munck and Dries Lyna (Farnham, Surrey: Ashgate, 2015), 213.

39 For instance, the mermaid of the Serena (Sirena) family, or the moon of the Lunas. Zecchin, Vetro, 2:182 and 3:72-77.

40 McCray, "Creating," 312-313, 316-323 and Sven Dupré, "The Value of Glass and the Translation of Artisanal Knowledge in Early Modern Antwerp," in Trading Values in Early Modern Antwerp, ed. Christine Göttler, Bart Ramakers, and Joanna Woodall (Leiden: Brill, 2014), 147-151.

41 See the case studies in Concepts of Value and the overarching view in De Munck's and Lyna's introduction: "Locating and Dislocating Value: A Pragmatic Approach to Early Modern and Nineteenth-Century Economic Patterns," in De Munck and Lyna, Concepts of Value, 1-29. 
craftsmanship became a distinctive feature, hence the need to secure distinctive knowledge under a monopolistic control over the industry, as was accorded by political authority. This association could thus be used as a substitute for a brand name on the international market.

On this matter, the attitude of the Venetian government played a central role. Among the city guilds, the glassmakers had benefited from a privileged position since the Middle Ages, but their definitive success followed the international recognition accorded to crystal glass, mirroring the city's status as a major centre of luxury manufacture. It was, then, the instant fascination cristallo held over the elites of the time, and the desire this exclusive material evoked among those at the head of the political, social, and cultural spheres, that turned it into a state affair. The workshops in Murano started to be included in the customary tour of the city's marvels organized for notables visiting Venice. The Serenissima was more than willing to exploit foreigners' fascination for the glass making process and the uniqueness of the site where it happened (Fig. 2.2). Besides, as a cross-cultural material, glass made for the perfect diplomatic gift, which the republic could subtly use to gain foreign benevolence, especially in the case of its high-end products. ${ }^{42}$

In this context, the highest bodies of the state conveniently supported an already existing oligarchy within the guild which ultimately left one of the most recognizable crafts produced in the Lagoon under the control of a small group of families. In a sector in which expertise was primary, and the provision of raw materials was completely under the supervision of the guild, limiting access to its highest ranks reinforced among its members the identification between the guild and its products, the guild and the city, and finally the city as a protector of an identifiable business.

This perception was strengthened by the direct relationship between the guild and the city's highest governing bodies. Two moments marked this bond. In 1469 the basis for the success of the oligarchic aspirations of the major families (and the most ambitious newcomers) who worked on the island was founded with a ducal letter. It did not simply reaffirm the general monopoly of Muranese manufacturing, but also established a clear hierarchy among the islands' workers, based on their

\footnotetext{
42 Marta Ajmar-Wollheim and Luca Molà, "Cross-Cultural Objects in the Early Modern Period," in Global Design History, ed. Glenn Adamson, Giorgio Riello, and Sarah Teasley (London: Routledge, 2011), 12-13. In Venetian diplomacy, the fame of glass was especially exploited for relations with the Ottoman court and the recurring exchange of gifts "requested" by the Islamic side. It united the political role of "giving" as an act of honour with the use of gifts to ease contention. Glass goods constituted market transactions that could be counter-gifted. On the role of gifts in pre-capitalistic markets, Martha C. Howell, Commerce before Capitalism in Europe, 1300-160o (Cambridge: Cambridge University Press, 2010), 145-159, $171-207$. See also Deborah Howard, "Diplomacy and Culture," in Islamic Artefacts in the Mediterranean World: Trade, Gift Exchange and Artistic Transfer, ed. Catarina Schmidt Arcangeli and Gerhard Wolf (Venice: Marsilio, 2011), 161-172.
} 


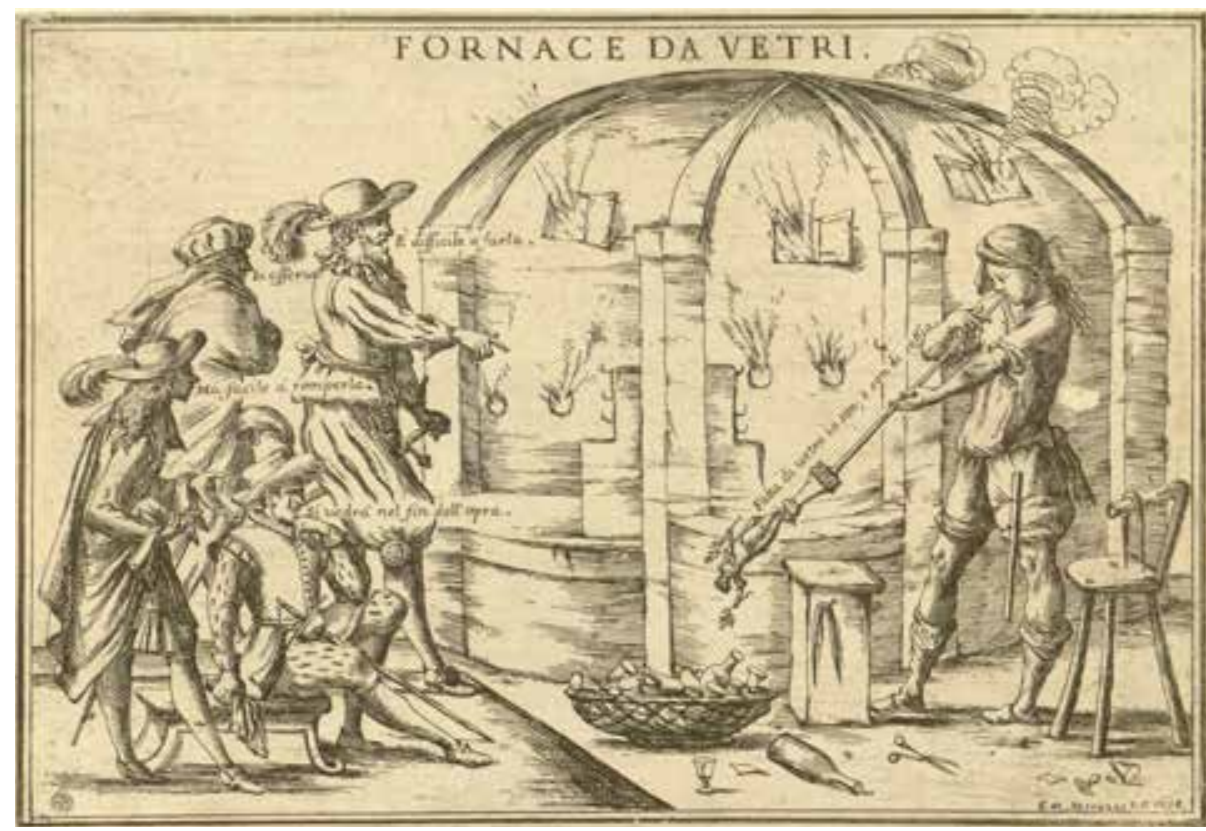

Figure 2.2: Giuseppe Maria Mitelli, Fornace da vetri, 1698. Etching, $211 \times 311 \mathrm{~cm}$. Milan, Castello Sforzesco, inv. no. RM m. 2-1. Image $\odot$ Civica Raccolta delle Stampe Achille Bertarelli - Castello Sforzesco - Milano.

origin. ${ }^{43}$ The state embraced the requests of leading families to protect their status and businesses, so from that year on, only people born in Murano were allowed to learn how to craft crystal or to own a furnace. Even business partners were permitted to come from only Murano or Venice.

The second turning point happened in 1482, when the Council of Ten decided to take the guild's regulations under its authority, which it would keep until the mideighteenth century. ${ }^{44}$ This direct relationship with the state's highest political body increased the power of the guild (especially over the other arti figlie), ${ }^{45}$ and marked their clear social distinction. ${ }^{46}$ This position was further reinforced by prohibiting the trade of crystalware in Venice, the only exception being the glassmakers' own stalls during the fair of the Sensa. Whoever wanted to buy crystal had to go to Murano to purchase it exclusively at the local shops. ${ }^{47}$

43 BMC, IV L 13, ch. 73, cc. 19r-21v (16.01.1468mv).

44 Trivellato, Fondamenta, 19.

45 Until that moment the guild had been subject to the customary magistrates: the Old Justice and the Provveditori di Comun, which remained in charge of the other guilds' glass-working procedures.

46 McCray, “Creating," 310.

47 BMC, IV L 13 , ch. $74-76$, cc. 22 r-23r (18.01.1481mv). See also the conflicts with glass sellers (ASVe, Arti, 725 , ch. $36\left[31.03 .15^{22}\right]$ and $\left.44\left[28.04 \cdot 15^{23}\right]\right)$. 
The reason was simple: glass was beneficial to the city's economy and image, thus the demands of its prominent families had to be supported, as long as they continued to be profitable for the state. In cases of internal conflict, the authorities would have used their power to correct excesses or impose their will. It was a sentiment shared among the governmental authorities, expressed for instance a few years later in the Senate's deliberation to reiterate the aforementioned prohibitions. The Pregadi explained these actions were taken to preserve and encourage the Muranese glass industry, which was of great benefit to Venice. ${ }^{4}$

Thanks to favourable state policy, the glass trade largely stayed in the hands of its Muranese leaders during the early modern period. In fact, the patriciate usually did not take part in glass trading at all, limiting their interest to their political prerogatives. Venetian patricians were arguably more interested in the way they could use the fame of glass as a political tool rather than for personal profit. ${ }^{49}$ Glass entrepreneurs reciprocated, offering certain (not codified) product standards around luxury items to appeal to elites..$^{50} \mathrm{In}$ its most common form glass provided a mass consumption commodity that sustained the Venetian hub, as was the case with plain tableware (Fig. 2.3).

In contrast to the textile industry, glass manufacture was left to the will of its producers, as neither the state nor the guild ever imposed pre-fixed standard levels around production. Moreover, during the Renaissance, general technological prescriptions became even less strict, compared to the Middle Ages..$^{5}$ These freedoms sustained a certain level of competition among the guild's glassmakers, a condition which for a century promoted a positive attitude towards experimentation and resulted in the products that sealed the fortune of both Venetian glassware and the oligopolistic group controlling it..$^{2}$ It encouraged innovation and the competitive circulation of those collective, yet subtle, secrets that made Muranese glass identifiable and highly valued, while creating the conditions for the birth of an unofficial brand that was based on the city of Venice itself, rather than on the names of single workshops.

An impression of the wide range of innovative items that resulted from these favourable conditions can be found in the inventories of the period's Muranese

48 Ibid., ch. 102, cc. 29v-30v (31.10.1489).

49 On the cultural role of glass within Venetian society see the first and second paragraphs of Lucas Burkart's chapter in this book.

$5^{0}$ These were largely based on the monopolistic use of the highest quality raw materials, see Monticolo, I capitolari, 2:89, and the scarce market participation of lower quality Spanish ashes, see Rafael María Girón-Pascual, "Cenizas, cristal y jabón. El comercio de la barrilla y sus derivados entre España e Italia a finales del siglo XVI," eHumanista 38 (2018): 221-225.

$5^{1}$ Corinne Maitte, "Labels, Brands, and Market Integration in the Modern Era," Business and Economic History 7 (2009): 13-16.

52 On this trend in European proto-industry see Stephan R. Epstein, "Craft Guilds, Apprenticeship, and Technological Change in Preindustrial Europe," The Journal of Economic History 58, no. 3 (1998): 693-705. 


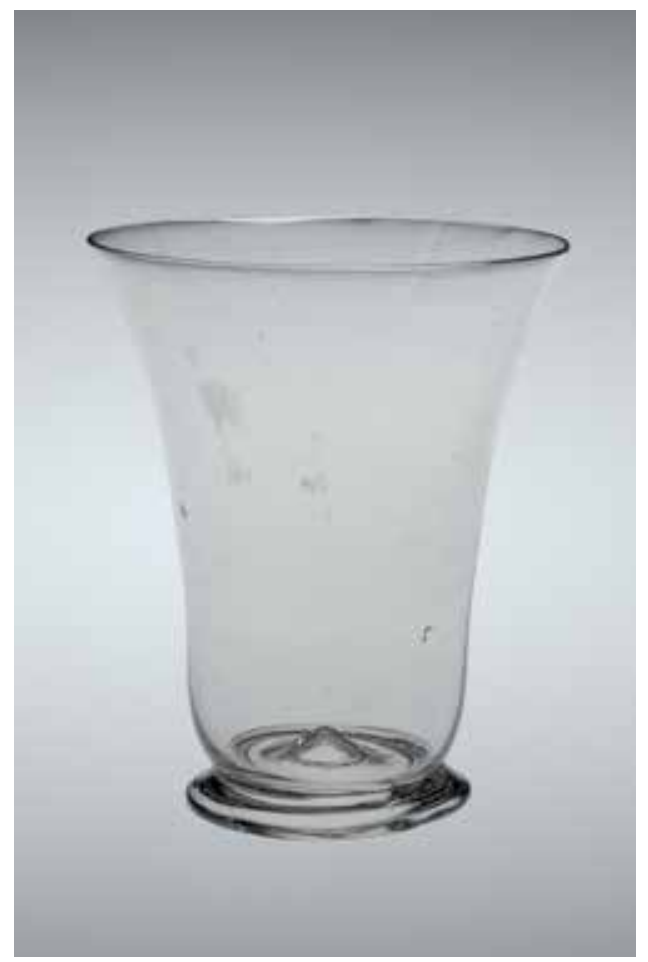

Figure 2.3: Blown colourless glass beaker, seventeenth century. $\mathrm{H}: 8.6 \mathrm{~cm}$, Rim D: $7.2 \mathrm{~cm}$. Corning, NY, The Corning Museum of Glass, inv. no. 2009.3.89. Image $\odot$ The Corning Museum of Glass.

glass shops. ${ }^{53}$ At the beginning of the seventeenth century, Marco Barovier was selling different types of crystalware (chrestali di diverse sorti), such as jugs, vases, ewers, tazze, and all kinds of drinking vessels in hundreds of pieces, together with little statues in the shape of animals. Precious crystal and filigree items were also available in abundance at his shop, as well as common objects like tavern ewers (grosse da hostaria) and chamber pots. He even traded lamps and windowpanes. ${ }^{54}$ Some years later, the Dall'Aquilas were also selling crystalware and chalcedony glass in Padua in the range of hundreds of pieces, ${ }^{55}$ while Cristina Brunoro had items totalling 1,484 ducats in her Milanese shop ( 850 of which were crystalware, equivalent to approximately 17,000 pieces). She also traded common glassware and frit..$^{6}$

53 Rosa Barovier Mentasti and Cristina Tonini, "Tools to Study Glass: Inventories, Paintings and Graphic Works of the 16th Century," in Study Days on Venetian Glass: Approximately 1600 , ed. Rosa Barovier Mentasti and Cristina Tonini, Atti, vol. 172, fasc. 1 (Venice: Istituto Veneto di Scienze, Lettere ed Arti, 2013-2014), 23-31.

54 ASVe, PodMur, b. 205, sd (04.09.1636).

55 Ibid., $s d(21.05 \cdot 1647)$.

56 Ibid., sd(o9.12.1672). 
Arguably, the situation had been similar during the previous century, when the quantitative and qualitative range of items displayed on shelves or stored in closets would have surely surprised any visitor. In 1578 the house of Gian Antonio Zanchi was full of all sorts of objects made in the local furnaces, waiting to be resold: gilded and filigree glass was available in dozens of shapes, together with enamelled glassware, figurines and reliefs, ice glass, and strings of beads (paternostri). ${ }^{57}$ The inventory of the house and shops of the glassmaker Antonio of Alvise, under the sign of the Three Moors (Ai Tre Mori), is equally rich, attesting to the ingenuity of the glass masters. ${ }^{5}$ Among the strangest and most expensive pieces, some of which must have been peculiar even for the period, included, for instance, thirty enamelled glasses in the French style decorated with coats of arms and a parrot cage (una cheba da papagà). By contrast, a completely different clientele would have bought what was in the shop of Leonardo Caner: that is, house lamps and glassware for daily use. 59

In other cases, the inventories' results are less rich at first glance, for instance that composed for Giovanni Bortolussi's house in 1589. Regarding glass, the notary registered 700 mirror sheets, but no other product. ${ }^{60}$ More indicative of the dominance the Bortolussi family enjoyed over the century is another source, an earlier notebook kept by one of Giovanni's cousins while managing the family shop in Milan. ${ }^{61}$ It states, for instance, that several crates full of glassware had been sold between February and May 1540, comprehensive of some of the most recent and trendy innovations in glassmaking, fashioned into vessels of various shapes. In another record of eleven boxes, a remarkable number of items totalling more than 10,700 pieces were listed to be sent from Murano to Lombardy in the same year. Half of them were plain drinking glasses, footed vessels, or jugs aimed at everyday use, but less conventional products were present too. Some were gilded, and a few were decorated using new methods and included diamond-point engraved pieces and elegant, high-footed tazze enhanced by fine filigree. ${ }^{62}$

As shown by the above-mentioned examples, luxury artefacts were a significant part of Venetian glass production. Since they appealed to the richest representatives

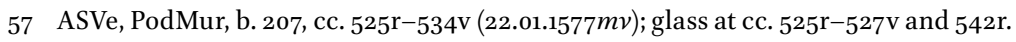

$5^{8}$ Ibid., cc. 114r-121r (9-10 and 17.11.1569), and cc. 118r-120r, 134r-136v (03 and 09.09.1570).

59 Ibid., cc. 311r-312v (24.06.1574). Among them: common glasses, cesendelli-lamps, lamps, ewers, chamber pots, and vessels for hair-dyeing (zucche da bionda).

6 o ASVe, GP, b. 339 (n. 4), inv. 82 (27.06.1589).

61 Zecchin, Vetro, 2:182.

62 Zecchin, Vetro, 2:187-188. Interestingly the notes hint at the prices of some objects: meze nose (receptacles shaped as walnut shells) of filigree glass were sold for between 4 and 9 soldi each, while the same items in plain glass cost 10 lire to the hundred (i.e. 2 soldi each). Overall, they were quite cheap. By contrast, vases worked with the more difficult to craft reticello technique could reach 2.5 lire apiece. 
of European and international families and courts ${ }^{6}{ }_{3}$ they could enhance the name of some masters while spreading the primacy of Venetian glass among refined social circles. ${ }^{64}$ But to continue to focus exclusively on them would have been a mistake. Even while high-end sales surely contributed to the profits of the branch, they could not sustain the industry alone. Yet, the reputation of such products was essential for the trade of glassware as a mass commodity, which was based mainly on glass beads, windowpanes, and mirrors, as well as plain glass. It can thus be argued that high- and low-end production went hand in hand, working in synergy.

For example, in 1461, a trial which positioned Marco and Giovanni Barovier against the merchant Marco Rosso was not about crystal but concerned a shipment of enamels to Syria, probably to supply artisans who specialized in metalwork. ${ }^{65}$ Moreover, the very existence of a glass-resellers' guild points to the solid market for common glass. ${ }^{66}$ As a series of chapters from 1482 in the glassmakers' guild's book show, even commerce with Germany was largely made up of windowpanes - called rui after their rounded shape - and common drinking vessels. ${ }^{6}{ }^{6}$ In the case of the windowpanes, the statutes prescribed that all orders from the German merchants of the Fondaco had to be spread among the members of the guild, while no workshop was allowed to sell more than 10,000 rui per single sale. ${ }^{68}$ Through rotation, the guild prevented conflicts among its associates in a trade that was inexpensive per item, but profitable in big numbers (Fig. 2.4) ${ }^{69}$

63 For example, in Florence, inventories prove that at the end of the fifteenth century Muranese novelties were already appreciated and displayed by major local families; see James R. Lindow, "For Use and Display: Selected Furnishing and Domestic Goods in Fifteenth-Century Florentine Interiors," Renaissance Studies 19, no. 5 (2005): 643-644.

64 In the 1570s members of the Tre Mori family moved to Florence to work for duke Cosimo I; later the Venetian Republic granted Cosimo II permission to call to his court the masters Luna. Cosimo I had had a personal interest in glassmaking, but arguably both Cosimos were well aware that the arrival of Venetian masters would have indirectly helped the technological upgrade of the local industry. See Zecchin, Vetro, 1:145-147 and 2:171-176; and Anna Laghi, "Migrazioni venete: influenza e originalità nella produzione vetraria toscana fra '50o e '6oo," Antichità Viva 26, no. 4 (1987): 43-51.

65 ASVe, GP, Sentenze a Giustizia, reg. 130, cc. $45 \mathrm{v}-46 \mathrm{v}$ (16.01.146omv).

66 Unfortunately, with the exception of crystal mirrors, the lack of information on glass stands out in Venetian sources, in which it is usually mentioned only as containers of unspecified items. A large survey on fifteenth/sixteenth-century inventories (e.g. the hundreds in ASVe, Cancelleria Inferiore, Miscellanea, Inventari, bb. 34-38), has proved that in Venice the interest for high-range glass artefacts was below the bar until the middle of the seventeenth century. Instead, it can be argued that common glass must have been quite easy to find. Its absence in the sources could be due to its very cheap price and rapid turnover.

67 Zecchin, Vetro, 2:37-38.

68 Respectively BMC, IV L 13, ch. 91, c. 27r and ch. 98 , c. 28r-v.

69 Contemporary quantitative sources (e.g. fiscal ones) on export and internal consumption are not available for the period, but a rough idea can be grasped when compared against the data available for 


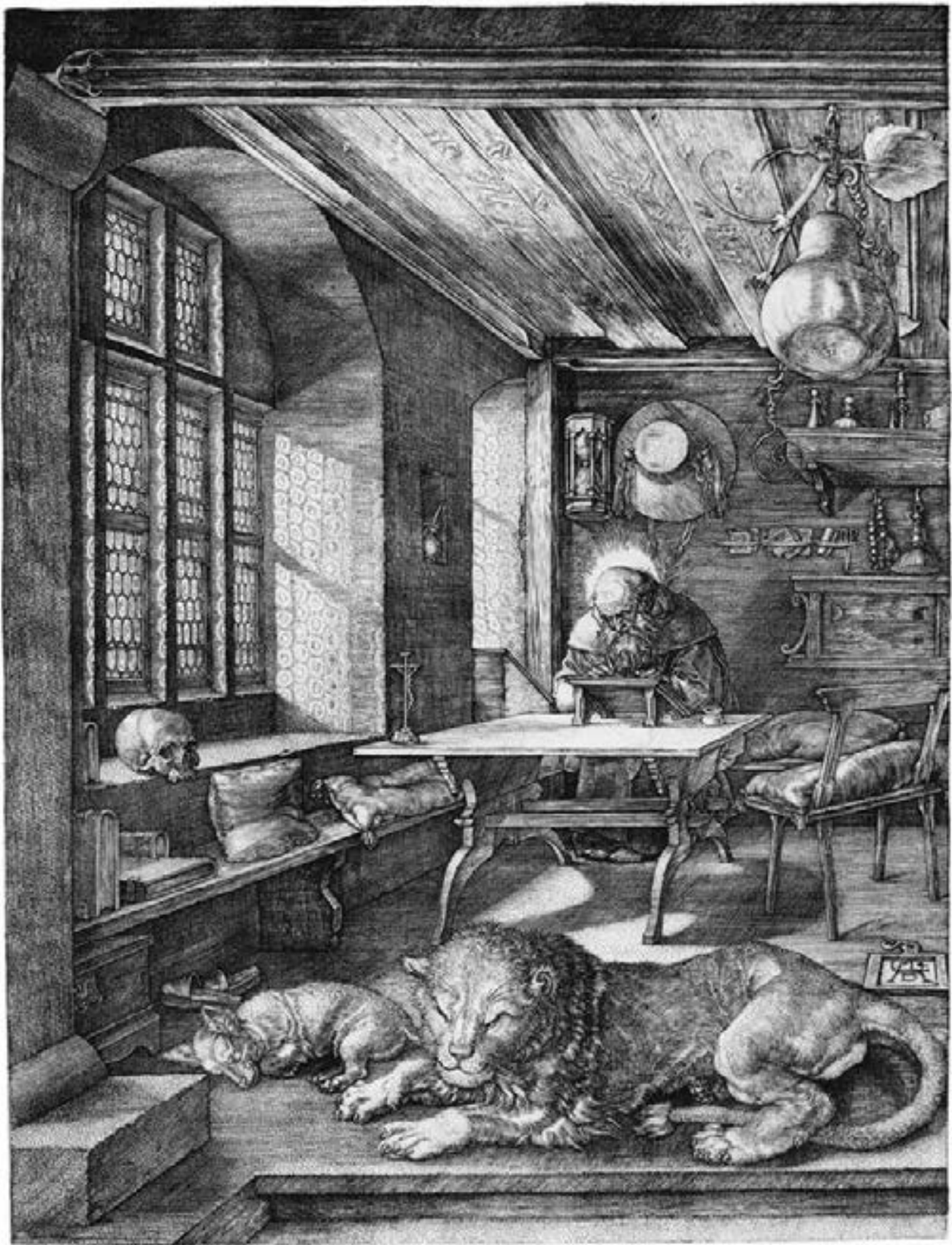

Figure 2.4: Albrecht Dürer, Saint Jerome in His Study, 1514. Engraving, $25 \times 20 \mathrm{~cm}$. Karlsruhe, Staatliche Kunsthalle, inv. no. I 834. Image ๑ Staatliche Kunsthalle Karlsruhe. 
Lastly, this context favoured the emergence of a sense of Venetian innovation amongst its clientele. In fact, the years roughly between $145^{\circ}$ and $155^{\circ}$ marked a unique phase in the history of glass innovation and restyling: first cristallo, promptly followed by lattimo, then new shapes in glass beading and the rediscovery of chalcedony glass. ${ }^{70}$ The following decades saw even stronger modernization. In 1527 the Serena brothers patented filigree glass, ${ }^{71}$ and in 1549 Angelo dal Gallo claimed the technique used to engrave a glass surface with a diamond (Fig. 2.5). $7^{2}$ In the meantime, unknown masters discovered how to produce the geometrical net ornamentation typical of reticello, while in 1507 Angelo's relatives had already obtained a twenty-year patent for the discovery of a method to produce mirrors from crystal glass, ${ }^{73}$ which by the end of the century became Venice's major glass production. ${ }^{74}$

The ability to master new solutions and ideas, and to share them in a competitive but collective atmosphere, remained a compelling force behind Muranese production until the end of the sixteenth century, despite a slowdown after the 1560 s and a shift towards micro-improvements rather than macro innovations. During these decades glassmakers collectively responded to the new populuxe demand, ${ }^{75}$ sharing their expertise.$^{6}$ The results actively looked to find improved solutions to satisfy the desires coming from customers, especially the urban middle classes. After glass had been used to imitate other more expensive luxury materials, Muranese entrepreneurs precociously sensed the emergence of new stylistic values and the resulting market. They succeeded because they moulded the material to meet new tastes. They abandoned copying and responded with originality and uniqueness to contemporary sensitivities. In doing so, they set a new distinctive fashion for glass based on shape, transparency, brilliance, and new chromatic tastes. Shape, especially in the case of blown objects, overtook material preciousness, while

the last decades of the eighteenth century, summarized in Trivellato, Fondamenta, 230-232.

70 Gianni Moretti, "La Rosetta. Storia e tecnologia della perla di vetro veneziana più conosciuta al mondo," Rivista della Stazione Sperimentale del Vetro 1 (2005): 27-39; and on the history of glass jewels Barbara Bettoni, Perle divetro e gioie false. Produzioni e cultura del gioiello non prezioso nell'Italia moderna (Venice: Marsilio, 2017).

71 ASVe, CX, Deliberazioni, Comuni, reg. 3, cc. 111v-112r (19.10.1527) and ASVe, NotT, b. 203, c. 174r-v (o8-09.08.1538). By that time the style was already widespread in Murano.

72 ASVe, Senato, Terra, filze, f. 9, fasc. "Vincenzo de Anzolo dal Gallo" (28.01-03.08.1549).

73 ASVe, CX, Misti, reg. 31, c. 125r (19.05.1507) and fil. 20, n. 103 (19.05.1507).

74 Paolo Zecchin, “Gli specchi veneziani," Rivista della Stazione Sperimentale del Vetro 6 (1993): $299-307$.

75 The term refers to the lower-end luxury goods that became popular among large segments of the population during the Renaissance; Francesca Trivellato, "Guilds, Technology, and Economic Change in Early Modern Venice," in Guilds, Innovation, and the European Economy, 140o-180o, ed. Stephan R. Epstein and Maarten Prak (Cambridge: Cambridge University Press, 2008), 204.

76 McCray, The Fragile Craft. 


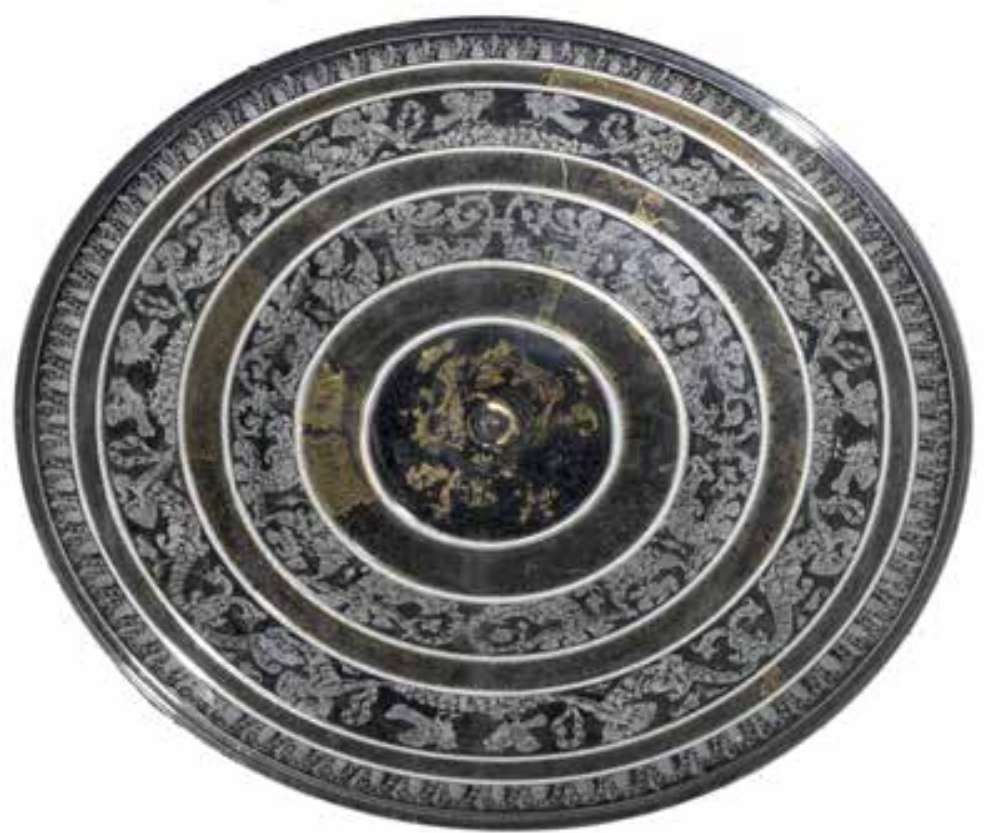

Figure 2.5: Diamond-engraved glass dish, with opaque white threads, cold-painted and gilded, ca. 1560s. W: $27.0 \mathrm{~cm}$ max. London, Victoria and Albert Museum, inv. no. C.178-1936. Image ๑ Victoria and Albert Museum, London.

material effects came to surpass decoration. In particular, painted decoration was replaced by the subtle combination of transparency with simple but appealing touches of colour, or by the sophisticated play between crystal glimmer and the translucency that came from the white, thin lattimo strings of filigree (Figs. 2.6 and 2.7).

This new Venetian style was not simply the expression of a new concept of beauty. Seen from a managerial point of view, it was also functional. Its methods generally excluded other guilds like painters and put all the production stages in the hands of the furnace staff. It made it possible to work the objects entirely in the same space, increasing control over the whole production process as well as easing the planning of future trends. Moreover, these new techniques usually resorted to far less costly raw materials, above all by limiting the recourse to gold, as gilded surfaces progressively diminished in appeal. The case of ice glass is emblematic: a surprising and beautiful effect resembling cracked ice was gained just from using cold water, dexterity, and a strong familiarity with the reaction of the material to the thermal shock (Fig. 2.8). In sum, the birth of fresher stylistic values in Venetian glass manufacture was not just a de facto way of branding without a brand by 


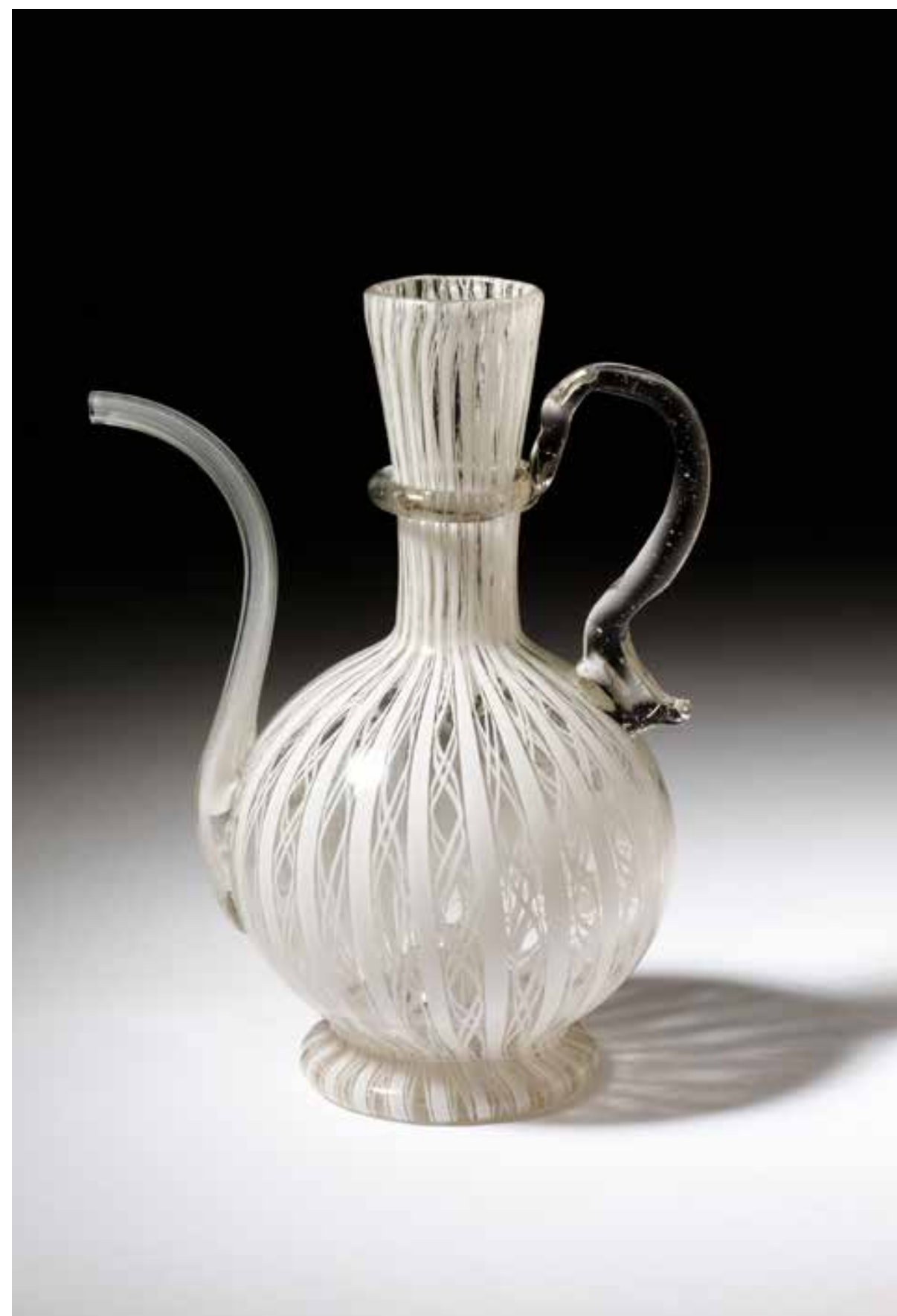

Figure 2.6: Ewer of filigree glass ("a retortoli" and "a fili"), ca. 1575-1600. H: $11.5 \mathrm{~cm}, \mathrm{~W}: 9.0 \mathrm{~cm}$ max. London, Victoria and Albert Museum, inv. no. 1914A-1855. Image ๑ Victoria and Albert Museum, London. 


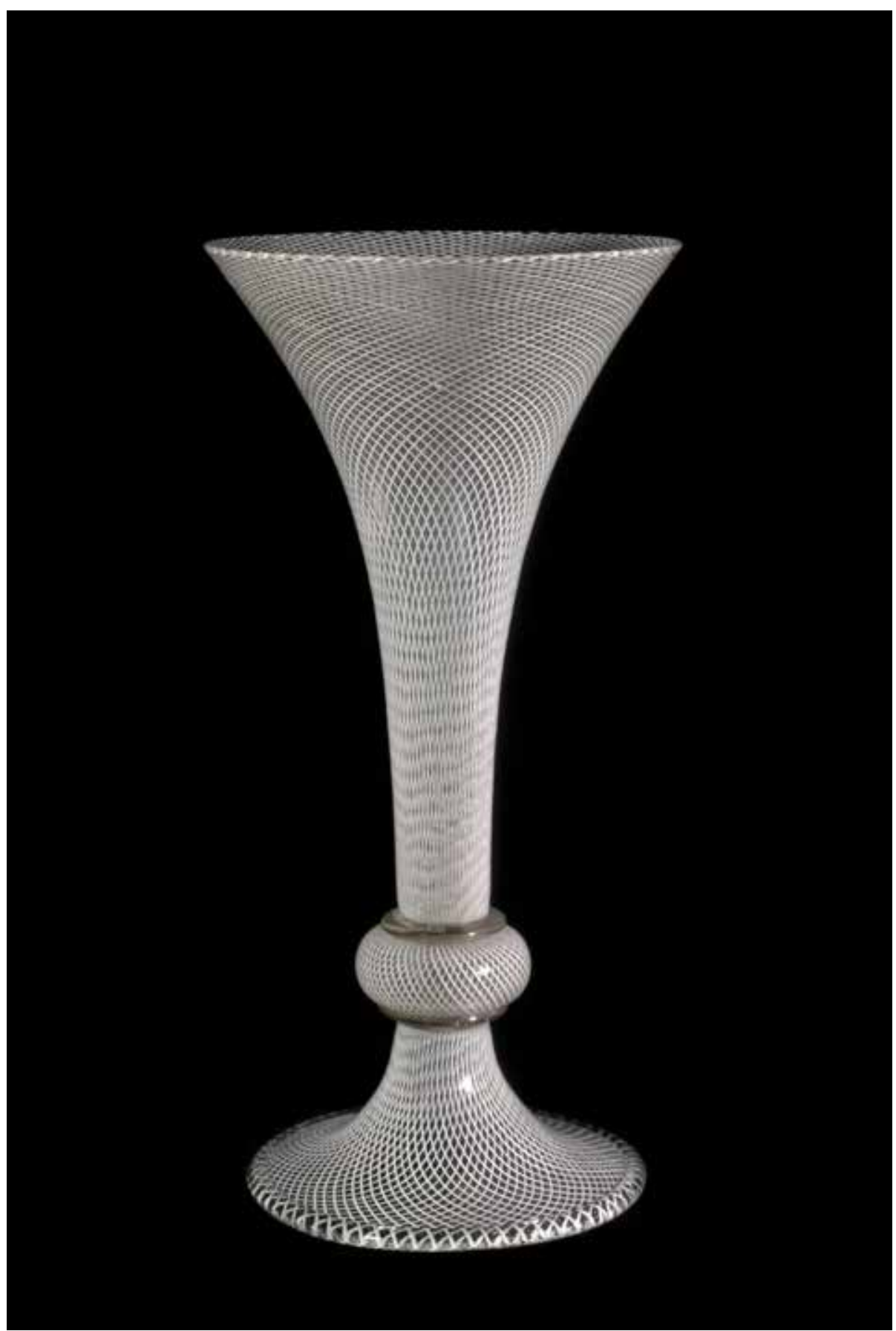

Figure 2.7: Reticello goblet, ca. 1575-1600. H: $30.5 \mathrm{~cm}, \mathrm{~W}: 15.3 \mathrm{~cm}$. London, Victoria and Albert Museum, inv. no. 1816-1855. Image $\odot$ Victoria and Albert Museum, London. 


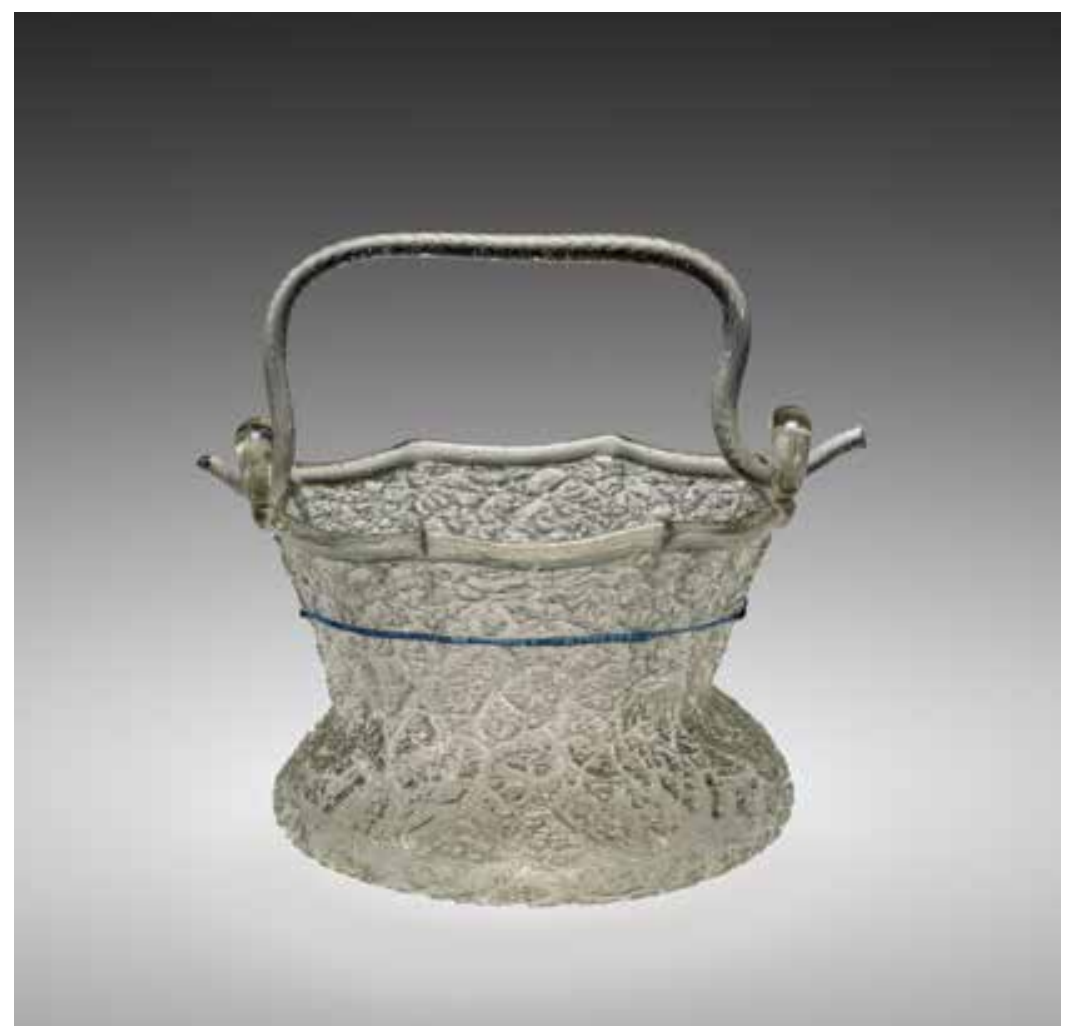

Figure 2.8: Ice glass aspersorium, seventeenth century. $\mathrm{H}: 11.4 \mathrm{~cm}, \mathrm{~W}: 16.8 \mathrm{~cm}, \mathrm{D}: 13.9 \mathrm{~cm}$. Corning, NY, The Corning Museum of Glass, inv. no. 2000.3.5. Image @ The Corning Museum of Glass.

means of stylistic techniques; it also stimulated experimentation to create items which could be put totally under the productive and commercial control of glass entrepreneurs, while reducing costs. In this, the state eased the process, protecting the guild and its leaders since their entrepreneurial success had beneficial results for both Venice's economy and its international prestige.

\section{Professional Identity and Social Ascent: The Case of the Bortolussi Family}

The case of the Bortolussis offers a vivid example of the strategies adopted by those families that used the success of the glass sector to improve their social and economic position as merchant-entrepreneurs and aspiring cives. The family most likely originated in Rimini and moved to the Venetian dominion before the end of the fourteenth century, when, in 1381, they gained privileges for helping defend the city port during 
the War of Chioggia.77 They did not become involved in glassmaking, however, for at least a century. Domenico Bortolussi, the forefather of the Muranese glassmakers, spent his life as a water carrier and participated in the glass sector only as a trader of wood to supply the furnaces. Yet, in doing so, he had become recognized as a Muranese civis and had held public offices, a condition that allowed his two sons to engage in the glass industry despite the lack of an earlier familial tradition. Regardless of being a first-generation glassmaker, Bortolo became the owner of a furnace under the sign of the "Ship" and even managed to reach the head of the guild by 1528, while his brother Iacopo was among the Muranese glass traders at the Lanciano fairs in $1531 .^{7}$

Bortolo and Iacopo initially operated as a fraterna, and by the 1540 s were already managing a business generating several thousand pieces a year. Thus, thanks to their entrepreneurial approach, by the middle of the century they were able to gain a solid position among the most powerful dealers in the sector. It is important to note that they benefited from the protectionist stance of the republic to strengthen their business and status; yet, to secure their social ascent, they needed to combine patrimonial growth with a wise matrimonial strategy. Their dual aim was to maintain a prominent position within the guild and the Muranese community, while also forging bonds of affinity with prominent families from the capital.

Bortolo's branch of the family, comprising eight sons and three daughters, exemplifies this tendency (Fig. 2.9). ${ }^{79}$ In fact, the paths of Bortolo and Iacopo eventually diverged so much that, at a later stage, the names of the former and his heirs are the only ones to appear in relation to glass. Hence, it was Bortolo who sealed the connection between his family and the glass business. To do so, among other things, he arranged the marriage of his daughter Cecilia into another emerging family, the Darduins. ${ }^{80}$ The girl wed Vincenzo, who was then building his firm, despite

77 ASVe, Miscellanea Codici, Storia Veneta (Cittadinanze Tassini), vol. VII (B-C), b. 10, pp. 398-400 and ibid., Storia Veneta (Cittadinanze Toderini), vol. I (A-B), b. 4, c. 381 r. See also the chapter in Anna Bellavitis, Identité, mariage, mobilité sociale. Citoyennes et citoyens à Venise au XVIe siècle (Rome: École Française de Rome, 2001), 269-273. In 1389, to reward foreigners who stayed in the city during the war, Venice eased the acquisition of citizenship for those who had asked for it within one year, see Reinhold C. Mueller, Immigrazione e cittadinanza nella Venezia medieval (Rome: Viella, 2010), 28. Still, there is no evidence that any Bortolussis took this opportunity.

78 On the first documented appearances of the Bortolussis in Murano: Zecchin, Vetro, 2:186-189; in Lanciano: Corrado Marciani, "Il commercio dei cristalli alle fiere di Lanciano nel secolo XVI," Archivio Storico per le Province Napoletane 39 (1959): 315, 320.

79 ASVe, NotT, b. 209, c. 82r (10.02.1556). See also Bellavitis, Identité, 269.

80 See Bellavitis, Identité, 269-270. On the Darduin family: Zecchin, Vetro, 2:167-170. The family descended from a German glass packer working at the Fondaco dei tedeschi who married a Muranese woman. In the late sixteenth century, it was within their circle that the most famous recipe book of Venetian glassmaking was written; see Luigi Zecchin, Il ricettario Darduin. Un codice vetraio del Seicento trascritto e commentato (Venice: Arsenale Editrice, 1986). 


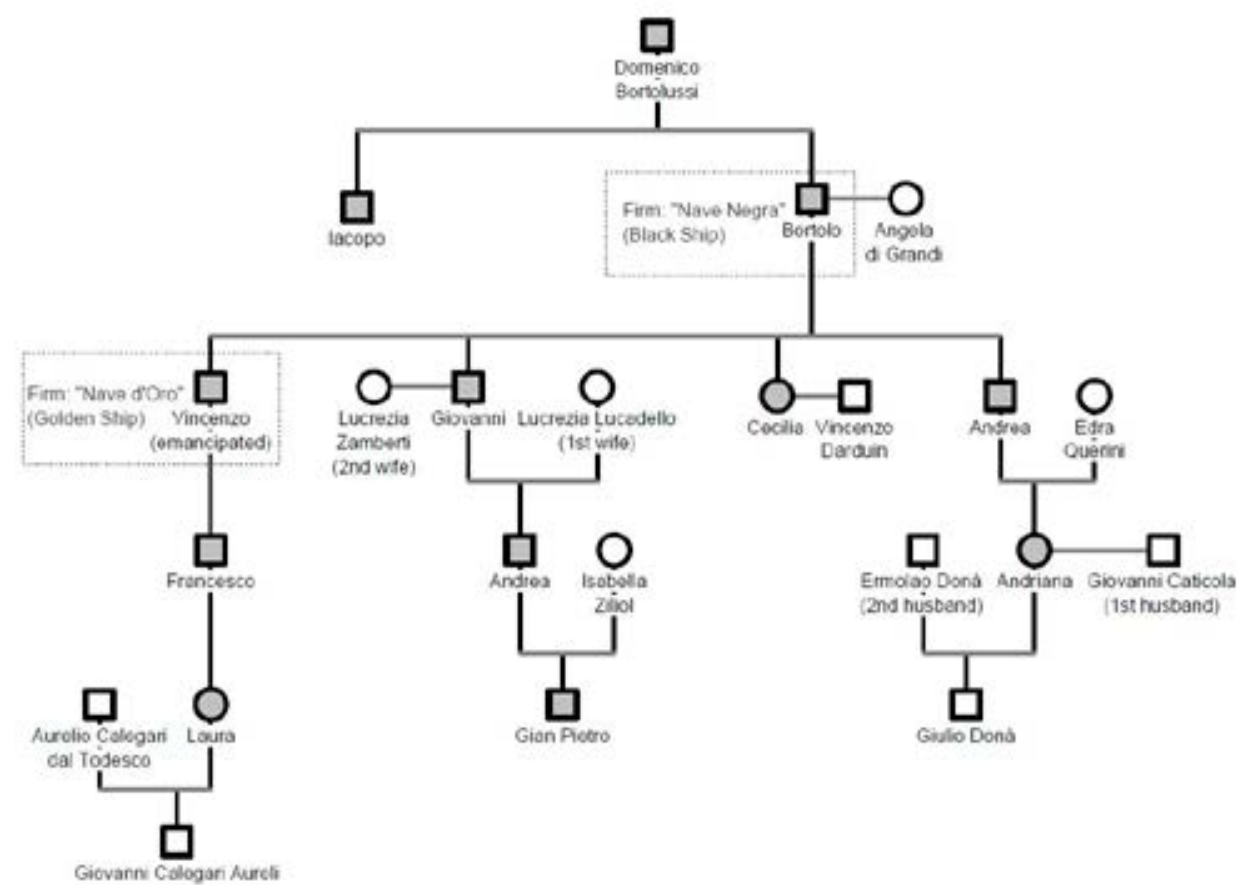

Figure 2.9: Scheme of the relations existing among the members of the Bortolussi family (in grey) and their relatives. The model depicts only the individuals mentioned in the chapter, and not the full family tree. Image @ Rachele Scuro.

the fact that in 1566 his sons had been accused of illegally opening their furnace, ${ }^{81}$ lacking the mandatory Muranese citizenship. ${ }^{82}$ It took decades for the Darduins to be officially recognized as rightful guild members and owners of a furnace..$^{83}$ However, in the uncertain moment of consolidation, the relationship between the two families helped them both to reinforce their place in the industry.

With regard to the male line, Bortolo's son Vincenzo emancipated quite early in order to open his own furnace. The decision launched another branch of the family, which distinguished itself from the paternal line by its sign. Bortolo and his lineage kept the original black ship (Nave Negra), while Vincenzo's vessel became golden-coloured (Nave Aurea or Nave d'Oro). ${ }^{84}$ His choice was not followed by his

81 ASVe, PodMur, b. 213, $s d(13.05 \cdot 1560)$.

82 Ibid., $s d(26.11 .1560)$.

83 BMC, IV L 13 , ch. 140, c. 59 r (21.06.1581).

84 In 156o Vincenzo's daughter Giulia married Piero, son of Domenico Ballarin (ASVe, NotA, reg. 3265, c. 101r-v [21.02.156o] and cc. 291r-292r [25.02.156o]). This union with one of the most important families of the island allowed Vincenzo to solidify his position in the industry, as Giulia's father-in-law was not only a master but also an influential entrepreneur. Arguably Vincenzo used an earlier family alliance 
brothers, however, who continued to manage the family business together, later joined by their male children. In the following years, between the 1550 and the 1570s, a series of deaths left Giovanni at the head of the family for more than twenty years. This partnership was, however, broken when the cousins entered adulthood.

Up to that moment, Giovanni had followed the path traced by his father before him, both in networking and in his trading strategies. Three of his brothers had married into the Venetian patriciate (namely the Querini family), ${ }^{85}$ and the same plan was followed once he and his surviving brothers faced the task of finding suitable spouses for their offspring. For example, when Piero made his will in 1568, he asked his brothers to find proper husbands for his daughters. ${ }^{86}$ Once again, the uncles favoured partners from honourable Venetian families rather than from the island's elite.

The family's marriage strategy had obviously progressed. First, it had secured their professional relationship within the Muranese milieu and the guild by means of Cecilia's marriage to a Darduin, while choosing wives from the patriciate or the cittadini originari families for the majority of Bortolo's sons. In the next generation, women also took part in this process of social promotion by means of their marriage. This peaked in 1596, when Andriana (daughter of the late Andrea) married the nobleman Ermolao Donà for her second marriage. The significant amount of 6,0oo ducats required for her dowry could not have been gathered without the effective management of the family patrimony during the previous decades. ${ }^{87}$

When the fraterna was split in 1588, a detailed list of all the goods was drawn up, to be divided into the individual family branches. The assets were apportioned into four parts: one share passed to Giovanni's line while the others went to the male heirs of his deceased brothers. ${ }^{88}$ The list covered fourteen folios and included hundreds of movable goods, as well as real estate in Murano, Venice, and in the district of Treviso, ${ }^{89}$ making up a combined value of several thousand ducats. Interestingly, credits and debts were also counted, thus providing important information about their trade. Their furnace (inclusive of glassware) was valued to 4,062 ducats - plus 523 ducats in mirrors - and comprised credits obtained in Lisbon for more than 7,200 ducats, in Sicily for 5,000 , in Seville for 1,288, and in Constantinople for over

to secure the wedding agreement, as before the Bortolussis entered glassmaking, one of their daughters married a natural son of the late Giorgio Ballarin, see Cesare Moretti and Tullio Toninato, eds., Ricettario vetrario del Rinascimento. Trascrizione da un manoscritto anonimo veneziano (Venice: Marsilio, 2001 ), 15. 85 Their wives were three sisters, too, as stated in Edra and Elisabetta's testaments; ASVe, NotT, b. 209, n. $191(11.02 .1556)$ and n. $84(25.11 .1562)$.

86 Bellavitis, Identité, 271 and ASVe, AvC, b. 373/13, fasc. 23 (11.08.1568).

87 ASVe, AvC, b. 114, n. 774 (o2.08.1596) and AvC, b. 9o, cc. 109v-110r (26.11.1596 and 16.04.1597). See also Bellavitis, Identité, 272.

88 ASVe, NotA, b. 3311, sd (01.07.1588).

89 As reported of 1582 in ASVe, Dieci Savi sopra le Decime di Rialto, b. 167, n. 340; also in Bellavitis, Identité, 270. 
1,500 ducats. Their debts totalled 6,287 ducats and were mainly the result of the purchase of the raw materials needed for glass production.

The dissolution of the prosperous Bortolussis' business might have seemed an irrational decision, but it was motivated by the aspirations of the younger generations, to whom the status of mere glass entrepreneurs was no longer enough. Only Giovanni and his heirs were still interested in the furnaces as their main line of business, while the other family branches were already moving into other professional affairs and were more focused on the capital rather than on the island. ${ }^{\circ}$ This was a trend that several of Giovanni's descendants would also pursue during the following century. Consequently, their ties with glassmaking were to remain mostly indirect: as investors or as owners of buildings rented to professional glassmakers. Hence, by the third generation, the family did not strongly pursue social distinction within the boundaries of Murano as they had done earlier. ${ }^{11}$ They instead aimed at the opportunities offered by the Venetian bureaucratic apparatus and the liberal professions, probably also influenced by the familial imprinting coming from their mothers, wives, and relatives who were part of the Venetian group of the cittadini originari.

After the closing of Venice's Major Council at the beginning of the fourteenth century, and the concentrating of political power solely in the hands of the patriciate, citizenship had become a distinctive social status, more so than in other cities, where the prospect of entering the elite group was still possible, at least theoretically. For those excluded from political power, being a citizen became essential in order to fully participate in both local and overseas trading opportunities, as different privileges were subject to the type of citizenship a person owned. ${ }^{22}$ Furthermore, citizenship was crucial to differentiate oneself from the mass of the popolani and to start a career in public office. The latter, in particular, became more appealing after the decision of the Council of Ten to take under its control the Venetian chancery in 1462. As in the case of the glassmakers' guild, an unmediated relationship with the highest political body of the state was a sign of social distinction in itself.

Therefore, if after the crisis of Agnadello (1509), positions as state officials became more desirable, seen as a guarantee against economic difficulties, ${ }^{93}$ their appeal

90 In 1589 Giovanni created a new partnership with two of his nephews to trade various commodities (mercancie diverse); ASVe, PodMur, b. 234, c. 328r-v (13.05.1589).

91 This process found its conclusion between 1602 and 1605 with the creation of a Golden Book that listed the families of Muranese citizenship, modelled after the books of Venetian patricians and cives. See Vincenzo Zanetti, ed., Il Libro d'Oro di Murano (Venice, 1883).

92 During the last decades, historians have analysed in depth the condition of the Venetian citizen class, especially the immigrants who acquired this status. See: Brian Pullan, “'Three Orders of Inhabitants': Social Hierarchies in the Republic of Venice," in Orders and Hierarchies in Late Medieval and Renaissance Europe, ed. Jeffrey Denton (London: Macmillan, 1999), 147-168; and Mueller, Immigrazione.

93 Matteo Casini, "La cittadinanza originaria di Venezia tra i secoli XV e XVI. Una linea interpretativa," in Studiveneti offerti a Gaetano Cozzi, ed. Gino Benzoni (Padua: Il Cardo, 1992), 142-143, 145-148. 
increased further when in 1569 new laws rigorously defined the mandatory characteristics needed to enter the limited group of families that had meanwhile gained a monopolistic role in the Venetian administration. Firstly, one had to prove having been born in Venice, like his father and grandfather before him; and secondly, it was necessary to hold the more impalpable social and economic trait of being an "honourable" and "civil" man, in other words rich and not practising manual labour. From that moment on, being a cittadino originario was at once defined by binding requisites while also becoming a mandatory title to work as a state bureaucrat. More generally, they became the highest social rank among the non-noble people of Venice. ${ }^{94}$

It is compelling that, as anticipated, this path was chosen by Giovanni's descendants - his son Andrea and grandson Gian Pietro - in a matter of decades. The turning point occurred when, in 1624, Andrea asked for the recognition of this title for his son, producing a rich dossier to demonstrate the merits of his request. ${ }^{95}$ First, he proved the three required grades of ascendance. Gian Pietro's condition was reinforced by the family's marriage strategy to unite their children with members of the Venetian patriciate. Accordingly, the dossier highlights Gian Pietro's maternal line and the fact that his grandfather, Giulio Ziliol had held the high office of cancellier inferior..$^{6}$ This kinship established the basis for a further ascension, as the young man married a girl from a noble family of Treviso, the Avogadros. ${ }^{97}$ This was a second foreseeable choice for the Bortolussis, who during the previous century had accumulated real estate in that part of the Terraferma.

Nonetheless, beyond matters of lineage, the core of the request resided in the way Gian Pietro and his father were living, and how the late Giovanni had lived before them. What Andrea emphasized was that none of them had ever practised manual work. On the contrary, they had all lived honourably in the civil way: in Venetian terminology, none of the three maifece arte mecanica, et visse sempre civilmente et honoratamente..$^{8}$ Francesca Trivellato has highlighted the apparent contradiction in the double condition of being a citizen originario and a glassmaker,

94 On the evolution of Venetian citizenship: Andrea Zannini, Burocrazia e burocrati a Venezia in età moderna: i cittadini originari (sec. XVI-XVIII) (Venice: IVSLA, 1993); James S. Grubb, "Elite Citizens," in Venice Reconsidered: The History and Civilization of an Italian City-State: 1297-1797, ed. John Martin and Dennis Romano (Baltimore, MD and London: Johns Hopkins University Press, 200o), 339-364; and Bellavitis, Identité.

95 ASVe, AvC, b. 373/13, fasc. 23 (1624).

96 The two families shared not only a distant Ferrarese origin, but also their use of mercantile success to ascend Venetian society before turning to offices and liberal professions thanks to their cittadinanza originaria. On the Ziliols see Anna Bellavitis, "Quando la Seconda Corona della Veneta Repubblica si racconta': la Cronichetta de ca' Ziliol,” in Family Memoirs from Venice (15th-17th Centuries), ed. James S. Grubb (Rome: Viella, 200o), XXXIII-XXXIX.

97 ASVe, AvC, b. 373/12, fasc. 23 (26.06.1624).

98 Ibid., in the application (17.06.1624). 
because if the first implied a complete detachment from manual labour, the latter rather presumed a distinct practical knowledge, as the guild prescribed that only those who had passed the examination to become masters could own a furnace (in addition to possessing Muranese citizenship). ${ }^{99}$ Andrea and Gian Pietro might have only owned shares in the business and have never worked with glass (after all, Andrea had also moved to his father-in-law's house in Venice), but that was surely not Giovanni's case. Supposing it was unlikely that Giovanni actively worked at the furnace during his adult years heading the family business, he nonetheless must have practised during his youth.

In Venice the condition of rich merchants (especially of mercante grosso, who could trade overseas) had always been as civil, if not more so, than property owners. This was not a problem, though, as the Bortolussis were both. Yet, the separation from manual labour was an unavoidable trait too, and the condition of artifex mechanicus remained an insurmountable obstacle to gain the title. ${ }^{100}$ The ambiguity was there and proved difficult to solve, however, all seven testifiers confirmed Andrea's statements.

In addition, the applicant and his supporters highlighted a third mandatory attribute: being cultivated. This was also part of the prerequisites, along with possessing a set of distinctive habits in living and dressing that were socially recognized as privileged. Hence, to cover Giovanni's weaker traits, attention was shifted to the characteristics typical of a "civil man" - first of all, the people he had practised with, and those exterior trappings that in the Renaissance played a fundamental role in social distinction. Some testifiers emphasized that he had had servants and owned a gondola, ${ }^{101}$ yet what everyone remarked upon was the way he dressed: that visible, material code that would have made his social status immediately discernible. Giovanni and all his male children wore the typical clothing of Venetian men belonging to higher social ranks: the distinctive $a$ comeo sleeves. ${ }^{102} \mathrm{He}$ was perceived as a merchant rather than a glassmaker, and a relative described him as the manager of a glass business, who had commercial employees and a shop at the sign of the Ship. ${ }^{103}$

99 Trivellato, Fondamenta, 94-97 and ch. 171 in the Mariegola dei Fioleri (1544).

100 Andrea Zannini, "Il 'pregiudizio meccanico' a Venezia in età moderna. Significato e trasformazioni di una frontiera sociale," in Le regole dei mestieri e delle professioni, secoli XV-XIX, ed. Marco Meriggi and Alessandro Pastore (Milan: Franco Angeli, 2000), 36-51.

101 ASVe, AvC, b. 373/13, fasc. 23 (19.06.1624) and (18.06.1624).

102 These are full sleeves closed at the wrist, a universally recognized exterior sign. They appear, for example, in Baldassare Castiglione, Libro del cortegiano (Venice, 1546), 63, and are also described as typically Venetian in Cesare Vecellio, De gli habiti antichi, et moderni di diverse parti del mondo libri due (Venice: Damian Zenaro, 1590), plate $5^{2}$. 103 ASVe, AvC, b. 373/13, fasc. 23 (24.06.1624). 
As a last confirmation of Giovanni's status, Marcantonio Barovier pointed out that the Bortolussi family had married some of its daughters into the Venetian patriciate and the cittadini originari families. ${ }^{104}$ On the matter of exogamic marriages between the nobility and non-nobles, Venice was more liberal than other cities and the Bortolussis had not shied away from establishing blood ties with patricians. Their family's origin and its connection to glass remained embedded in a sort of "mythological" tradition that attributed special privilege to glassmakers. In contrast to other popolane, their daughters would produce patrician heirs, if married to patricians. ${ }^{105}$ Beyond the myth, in those few instances when a girl whose ancestors were glassmakers married into nobility, this would usually have happened only after her family had completely abandoned the industry. At least in one significant case, however, it occurred while the bride's relatives were still glass entrepreneurs: the above-mentioned Andriana Bortolussi wed Ermolao Donà while her uncle (and father figure) was still in the glass business and her brothers held shares in the branch. Thus, it was Giulio, born to the couple in $1599,{ }^{106}$ who was probably the person Marcantonio Barovier referred to when reporting on nobles descending from Giovanni's nieces serving in the Major Council.

In the end, the successful outcome of the application marked the departure of that branch of the Bortolussi family from the business in Murano, as well as its final social ascent. It was an honourable way to enter the distinguished small circle of state bureaucrats or to diversify the social and professional role of some individuals through kinship. It was an honourable way to switch one profitable profession for another. ${ }^{107}$

The final question remains how this process was affected by the privileged status glassmaking held in comparison to other manual work. In other words, how did associations with glass affect the Bortolussis' initial condition and identity, contrasting with their claim of being "civil men" who were not to be considered artifices mechanici, even in the case of their grandfathers and ancestors. In this conflict between two identitarian backgrounds, glassmaking's position within Venetian society overcame obstacles of status and is indicative of their self-perception. It was a duality perfectly embraced by those who vouched for Giovanni Calegari Aureli's appointment of cittadinanza originaria in $1628 .{ }^{108}$

A kinsman of the Bortolussis, ${ }^{109}$ Giovanni was the owner of a furnace in Murano like his father and grandfather before him. Being a middle-aged man, he was not seeking this title in order to start a career in public office like his cousins, rather to

104 Ibid., (19.06.1624) and (26.06.1624).

105 Trivellato, Fondamenta, 97.

106 ASVe, AvC, reg. 57, c. 107 r.

107 Trivellato, Fondamenta, 101.

108 ASVe, AvC, b. 370/10, fasc. 70 (1628).

109 His mother was the granddaughter of Vincenzo from the family branch that established the shop Nave d'Oro. 
gain further social prestige. The fact that at the moment of his application he still operated in the glass industry created some initial problems, ${ }^{110}$ although it relays important clues about the opinions of the testifiers. The testifiers publicly explained why, due to the very nature of glassworking, those who held the highest positions within the glass profession were not to be considered mere manual workers. To them, glassmaking was not an ars mechanica, but an industria in the Latin sense of the word: like alchemy, it was based on distinctive expertise and ingenuity. It was not a matter of simple execution, but conceptual design and research. The Venetian tradition had already put some guilds in a privileged position, conferring to them a certain grade of "nobility" due to the symbolic value attributed to the materials they worked, ${ }^{111}$ yet glassworkers took this further, using it to sustain their right to benefit from a higher reputation among Venice's subjects.

The glassmaker Piero Carati states it plainly: "glassmaking is not a manual work, but an industria,"112 thus it would not have diminished one's respectability, even in the case of those masters and entrepreneurs who, every now and then, happened to work with their hands and not only run the business. Furthermore, two other testifiers affirmed that glassmakers were not to be considered akin to simple salaried craftsmen in any case, while a third stressed that Giovanni and his ancestors had never actually practised a mechanical art, and that if they had occasionally worked glass, it was only at their own furnace. ${ }^{113}$ Finally, to strengthen the superior position of glassworking over other industries, a last testimony stated that glassmaking was not humble artisanal work, rather an "honourable profession." The proof lay in the fact that it was the only guild to be put under the authority of the most important political body (i.e. the Council of Ten), while the others were subject to the common magistrates of the Old Justice. ${ }^{114}$

To conclude, after one and a half centuries the symbolic and political position of glass as a state affair had become part of the self-depiction of the industry and its men, together with its close relationship to the highest ranks of Venetian society: a commonly shared value among Venetians. Thus, for many (and first and foremost the glassmakers), it followed that the status of glassmaking was to be placed on top of the other arti with their weaker group identities. Since the mid-fifteenth century, the combined power of artistic innovation, trading success, political connections, and symbolic meaning had thus developed new social recognition for glassmaking, giving its richest entrepreneurial families the opportunity to be accepted as equals

110 ASVe, AvC, b. 370/10, fasc. 70 (o1 and 28.08.1628). The concession was first rejected. Once discussed again, it passed, although not unanimously.

111 Trivellato, Fondamenta, 91-94.

112 ASVe, AvC, b. 370/10, fasc. 70 (29.07.1628).

113 Ibid., (24 and 27.07.1628).

114 Ibid., (21.07.1628). 
by many of the Venetian elite, despite their artisanal origin. Some of those successful men, such as the Bortolussis, chose to use the new identity they had shaped through the glass industry to later pursue ambitions within the city and ultimately reach the highest positions commoners could aspire to in the republic. It was thanks to the development of this identitarian process that, when the incipient signs of a crisis within the glass industry came into focus by the end of the sixteenth century, they could use the connection and non-formal identification between Venice and the material of glass to secure something grounded in their cultural and sentimental sphere: their unique role within the society of the Serenissima.

\section{Bibliography}

\section{Unpublished Primary Sources}

Archivio di Stato di Venezia, Venice (ASVe)

Arti, 725, ch. 36, 44, 102

AvC (Avogaria di Comun), b. 9o; b. 114, n. 774; b. 370/10, fasc. 7o; b. 373/12, fasc. 23; b.

373/13, fasc. 23; reg. 57

Cancelleria Inferiore, Miscellanea, Inventari, bb. 34-38

CX (Consiglio dei Dieci), Deliberazioni, Comuni, reg. 3

CX (Consiglio dei Dieci), Misti, reg. 31; fil. 20, n. 103

Dieci Savi sopra le Decime di Rialto, b. 167, n. 340

GP (Giudici di Petizion), b. 339 (n. 4), inv. 82

GP (Giudici di Petizion), Sentenze a Giustizia, reg. 130

Miscellanea Codici, Storia Veneta (Cittadinanze Tassini), vol. VII (B-C), b. 10; Storia Veneta (Cittadinanze Toderini), vol. I (A-B), b. 4

NotA (Notarile, Atti), b. 3311; reg. 3265

NotT (Notarile, Testamenti), b. 203; 209, n. 84, 191

PodMur (Podestà di Murano), b. 19, 23, 26, 71, 116-117, 205, 207, 213, 234

Senato, Terra, filze, f. 9, fasc. "Vincenzo de Anzolo dal Gallo"

Biblioteca del Museo Correr, Venice (BMC)

IV L 13 (Mariegola dei fioleri, 1539-1544 ), ch. 73-76, 91, 98, 131, 135, 137, 140, 147

\section{Published Primary Sources}

Castiglione, Baldassare. Libro del cortegiano. Venice, 1546.

Vecellio, Cesare. De gli habiti antichi, et moderni di diverse parti del mondo libri due. Venice:

Damian Zenaro, 1590. 


\section{Secondary Literature}

Ajmar-Wollheim, Marta, and Luca Molà. "Cross-Cultural Objects in the Early Modern Period." In Global Design History, edited by Glenn Adamson, Giorgio Riello, and Sarah Teasley, 11-20. London: Routledge, 2011.

Ashtor, Eliyahu, and Guidobaldo Cevidalli. "Levantine Alkali Ashes and European Industries." Journal of European Economic History 12, no. 3 (1983): 475-522.

Barovier Mentasti, Rosa. "La vetraria veneziana." In Storia di Venezia. Temi. L’Arte, edited by Rodolfo Pallucchini, vol. 2, 845-905. Rome: Treccani, 1995.

Barovier Mentasti, Rosa, and Cristina Tonini. "Tools to Study Glass: Inventories, Paintings and Graphic Works of the 16th Century." In Study Days on Venetian Glass: Approximately 16oos, edited by Rosa Barovier Mentasti and Cristina Tonini, Atti, vol. 172, fasc. 1, 2-34. Venice: Istituto Veneto di Scienze, Lettere ed Arti, 2013-2014.

Bellavitis, Anna. “'Quando la Seconda Corona della Veneta Repubblica si racconta': la Cronichetta de ca' Ziliol." In Family Memoirs from Venice (15th-17th Centuries), edited by James S. Grubb, XXXI-LI. Rome: Viella, 2000.

Bellavitis, Anna. Identité, mariage, mobilité sociale. Citoyennes et citoyens à Venise au XVIe siècle. Rome: École Française de Rome, 2001.

Bettoni, Barbara. Perle di vetro e gioie false. Produzioni e cultura del gioiello non prezioso nell'Italia moderna. Venice: Marsilio, 2017.

Braunstein, Philippe, and Luca Molà, eds. Il rinascimento italiano e l'Europa, vol. 3: Produzione e tecniche. Vicenza: Angelo Colla, 2007.

Casini, Matteo. "La cittadinanza originaria di Venezia tra i secoli XV e XVI. Una linea interpretativa." In Studiveneti offerti a Gaetano Cozzi, edited by Gino Benzoni, 133-150. Padua: Il Cardo, 1992.

De Munck, Bert, and Dries Lyna, eds. Concepts of Value in European Material Culture, 1500-190o. Farnham, Surrey: Ashgate, 2015.

De Munck, Bert, and Dries Lyna. "Locating and Dislocating Value: A Pragmatic Approach to Early Modern and Nineteenth-Century Economic Patterns." In Concepts of Value in European Material Culture, 1500-1900, edited by Bert De Munck and Dries Lyna, 1-29. Farnham, Surrey: Ashgate, 2015.

Dupré, Sven. "The Value of Glass and the Translation of Artisanal Knowledge in Early Modern Antwerp." In Trading Values in Early Modern Antwerp, edited by Christine Göttler, Bart Ramakers, and Joanna Woodall, 139-161. Leiden: Brill, 2014.

Dupré, Sven, and Christine Göttler, eds. Knowledge and Discernment in the Early Modern Arts. London: Routledge, 2017.

Epstein, Stephan R. "Craft Guilds, Apprenticeship, and Technological Change in Preindustrial Europe.” The Journal of Economic History 58, no. 3 (1998): 684-713.

Finlay, Robert. "The Immortal Republic: The Myth of Venice during the Italian Wars (1494-1530)." The Sixteenth-Century Journal 30, no. 4 (1999): 931-944. 
Gasparetto, Astone. Il vetro di Murano dalle origini ad oggi. Vicenza: Neri Pozza, 1958.

Girón-Pascual, Rafael María. “Cenizas, cristal y jabón. El comercio de la barrilla y sus derivados entre España e Italia a finales del siglo XVI." eHumanista 38 (2018): 215-232.

Grubb, James S. "When Myths Lose Power: Four Decades of Venetian Historiography." The Journal of Modern History 58, no. 1 (1986): 43-94.

Grubb, James S. “Elite Citizens.” In Venice Reconsidered: The History and Civilization of an Italian City-State: 1297-1797, edited by John Martin and Dennis Romano, 339-364. Baltimore, MD and London: Johns Hopkins University Press, 2000.

Hankey, Ian. Video contribution to Ways of Making and Knowing: The Material Culture of Empirical Knowledge, edited by P. H. Smith, A. R. W. Meyers, and H. J. Cook. Chicago, IL: University of Chicago Press, 2014. Accessed on 19 August 2019. https://www.youtube. com/watch?v=sSBY6Lc2-hU.

Howard, Deborah. "Diplomacy and Culture." In Islamic Artefacts in the Mediterranean World: Trade, Gift Exchange and Artistic Transfer, edited by Catarina Schmidt Arcangeli and Gerhard Wolf, 161-172. Venice: Marsilio, 2011.

Howell, Martha C. Commerce before Capitalism in Europe, 1300-16oo. Cambridge: Cambridge University Press, 2010.

Jacoby, David. "Raw Materials for the Glass Industries of Venice and the Terraferma, about 1370 - about 1470." Journal of Glass Studies 35 (1995): 65-90.

Laghi, Anna. "Migrazioni venete: influenza e originalità nella produzione vetraria toscana fra '50o e “6oo." Antichità Viva 26, no. 4 (1987): 43-51.

Lane, Frederic C. "Family Partnership and Joint Venture in the Venetian Republic." The Journal of Economic History 4, no. 2 (1944): 178-196.

Lindow, James R. "For Use and Display: Selected Furnishing and Domestic Goods in Fifteenth-Century Florentine Interiors." Renaissance Studies 19, no. 5 (2005): 634-646.

Maitte, Corinne. "Larte del vetro; innovazione e trasmissione delle tecniche." In Il rinascimento italiano e l'Europa, vol. 3: Produzione e tecniche, edited by Philippe Braunstein and Luca Molà, 235-259. Vicenza: Angelo Colla, 2007.

Maitte, Corinne. "Labels, Brands, and Market Integration in the Modern Era." Business and Economic History 7 (2009): 1-17. On-line open access http://www.thebhc.org/sites/ default/files/maitte.pdf [checked 25.03.2019].

Maitte, Corinne. Les Chemins de verre. Les migrations des verriers d'Altare et de Venise (XVIe-XIXe siècle). Rennes: Presses Universitaires de Rennes, 2009.

Maitte, Corinne. "Les migrations de travail comme ressources: verriers altarais et vénitiens, XVIe-XVIIIe siècle." Mélanges de l'École française de Rome 123, no. 1 (2011): 33-47.

Maitte, Corinne. "Façon de Venise: Determining the Value of Glass in Early Modern Europe." In Concepts of Value in European Material Culture, 1500-1900, edited by Bert De Munck and Dries Lyna, 209-237. Farnham, Surrey: Ashgate, 2015.

Marciani, Corrado. "Il commercio dei cristalli alle fiere di Lanciano nel secolo XVI." Archivio Storico per le Province Napoletane 39 (1959): 315-324. 
McCall, Timothy, Sean Roberts, and Giancarlo Fiorenza, eds. Visual Cultures of Secrecy in Early Modern Europe. Kirksville, MO: Truman State University Press, 2013.

McCray, Patrick. "Creating Networks of Skill: Technology Transfer and the Glass Industry of Venice." Journal of European Economic History 28, no. 2 (1999): 301-333.

McCray, Patrick. Glassmaking in Renaissance Venice: The Fragile Craft. Aldershot: Ashgate, 1999.

Molà, Luca. The Silk Industry of Renaissance Venice. Baltimore, MD and London: Johns Hopkins University Press, 2000.

Molà, Luca. "Stato e impresa privilegi per l'introduzione di nuove arti e brevetti." In Il rinascimento italiano e l'Europa, vol. 3: Produzione e tecniche, edited by Philippe Braunstein and Luca Molà, 533-572. Vicenza: Angelo Colla, 2007.

Molà, Luca. "Inventors, Patents and the Market for Innovations in Renaissance Italy." In Italian Technology from the Renaissance to the Twentieth Century, edited by Anna Guagnini and Luca Molà, 7-34. History of Technology 32. London: Bloomsbury, 2014.

Monticolo, Giovanni, ed. I capitolari delle artiveneziane sottoposte alla Giustizia e poi alla Giustizia Vecchia. Dalle origini al MCCCXXX, vol. 2. Rome: Istituto Storico per le Fonti della Storia d'Italia, 1905 .

Moretti, Cesare, Carlo Stefano Salerno, and Sabina Tommasi Ferroni, eds. Ricette vetrarie muranesi. Gaspare Brunoro e il manoscritto di Danzica. Florence: Nardini Editore, 2001.

Moretti, Cesare, and Tullio Toninato, eds. Ricettario vetrario del Rinascimento. Trascrizione da un manoscritto anonimo veneziano. Venice: Marsilio, 2001.

Moretti, Gianni. "La Rosetta. Storia e tecnologia della perla di vetro veneziana più conosciuta al mondo." Rivista della Stazione Sperimentale del Vetro 1 (2005): 27-39.

Mueller, Reinhold C. Immigrazione e cittadinanza nella Venezia medieval. Rome:Viella, 2010.

Neri, Antonio. L'arte vetraria. 1612, edited by Rosa Barovier Mentasti. Milan: Il Polifilo, 1980.

Page, Jutta-Annette, ed. Beyond Venice: Glass in Venetian Style, 1500-1750. Manchester, VT: The Corning Museum of Glass, 2004.

Poni, Carlo, and Roberto Breveglieri. "Three Centuries of Venetian Patents 1474-1796." Acta historiae rerum naturalium nec non technicarum 17 (1982): 381-393.

Preto, Paolo. I segreti di Venezia. Spionaggio e controspionaggio ai tempi della Serenissima. Milan: il Saggiatore, 2010.

Pullan, Brian. “Three Orders of Inhabitants': Social Hierarchies in the Republic of Venice.” In Orders and Hierarchies in Late Medieval and Renaissance Europe, edited by Jeffrey Denton, 147-168. London: Macmillan, 1999.

Romano, Dennis. Patricians and Popolani: The Social Foundations of the Venetia Renaissance State. Baltimore, MD and London: Johns Hopkins University Press, 1987.

Simmel, Georg. "The Sociology of Secrecy and of Secret Societies." American Journal of Sociology 11, no. 4 (1906): 441-498.

Smith, Pamela H. "Historians in the Laboratory: Reconstruction of Renaissance Art and Technology in the Making and Knowing Project.” Art History 39, no. 2 (2016): 210-233. 
Taddei, Guido. L'arte del vetro in Firenze e nel suo dominio. Florence: Le Monnier, 1954.

Trivellato, Francesca. Fondamenta dei vetrai. Lavoro, tecnologia e mercato a Venezia tra Sei e Settecento. Rome: Donzelli, 2000.

Trivellato, Francesca. "Guilds, Technology, and Economic Change in Early Modern Venice." In Guilds, Innovation, and the European Economy, 1400-1800, edited by Stephan R. Epstein and Maarten Prak, 199-231. Cambridge: Cambridge University Press, 2008.

Veeckman, Johan, Sarah Jennings, et al., eds. Majolica and Glass: From Italy to Antwerp and Beyond. The Transfer of Technology in the 16th-17th Century. Antwerp: Stad Antwerpen, 2002.

Vermeir, Koen. “Openness versus Secrecy? Historical and Historiographical Remarks." The British Journal for the History of Science 45, no. 2 (2012): 165-188.

Vermeir, Koen, and Dániel Margócsy. "States of Secrecy: An Introduction." The British Journal for the History of Sciences 45, no. 2 (2012): 153-164.

Zanetti, Vincenzo, ed. Il Libro d'Oro di Murano. Venice, 1883.

Zannini, Andrea. Burocrazia e burocrati a Venezia in età moderna: i cittadini originari (sec. XVI-XVIII). Venice: IVSLA, 1993.

Zannini, Andrea. 'Il 'pregiudizio meccanico' a Venezia in età moderna. Significato e trasformazioni di una frontiera sociale." In Le regole dei mestieri e delle professioni, secoli $X V-X I X$, edited by Marco Meriggi and Alessandro Pastore, $36-51$. Milan: Franco Angeli, 2000.

Zecchin, Luigi. Il ricettario Darduin. Un codice vetraio del Seicento trascritto e commentato. Venice: Arsenale Editrice, 1986.

Zecchin, Luigi. Vetro e vetrai. Studi sulla storia del vetro, 3 vols. Venice: Arsenale Editrice, 1987-1990.

Zecchin, Paolo. “Gli specchi veneziani." Rivista della Stazione Sperimentale del Vetro 6 (1993): 299-307.

Zecchin, Paolo. "La cavata dei vetrai muranesi." Rivista della Stazione Sperimentale del Vetro 5 (1995): 207-218.

\section{About the Author}

Rachele Scuro gained her PhD in Medieval History at the University of Siena. She has worked at the Universities of Basel, Verona and Venice and has collaborated with the University of Cambridge, and is now a research fellow at the University of Milan-Bicocca. Her main research topics are the history of the Jews, and the economic history of the Venetian state. 